Document downloaded from:

http://hdl.handle.net/10251/115833

This paper must be cited as:

Requena-Peris, R.; Vargas, M.; Atarés Huerta, LM.; Chiralt, A. (2018). Biopolymers Carrying Essential Oils, or their Compounds, for Food Antimicrobial Packaging. Current Organic Chemistry. 22(12):1141-1156. doi:10.2174/1385272822666171129153011

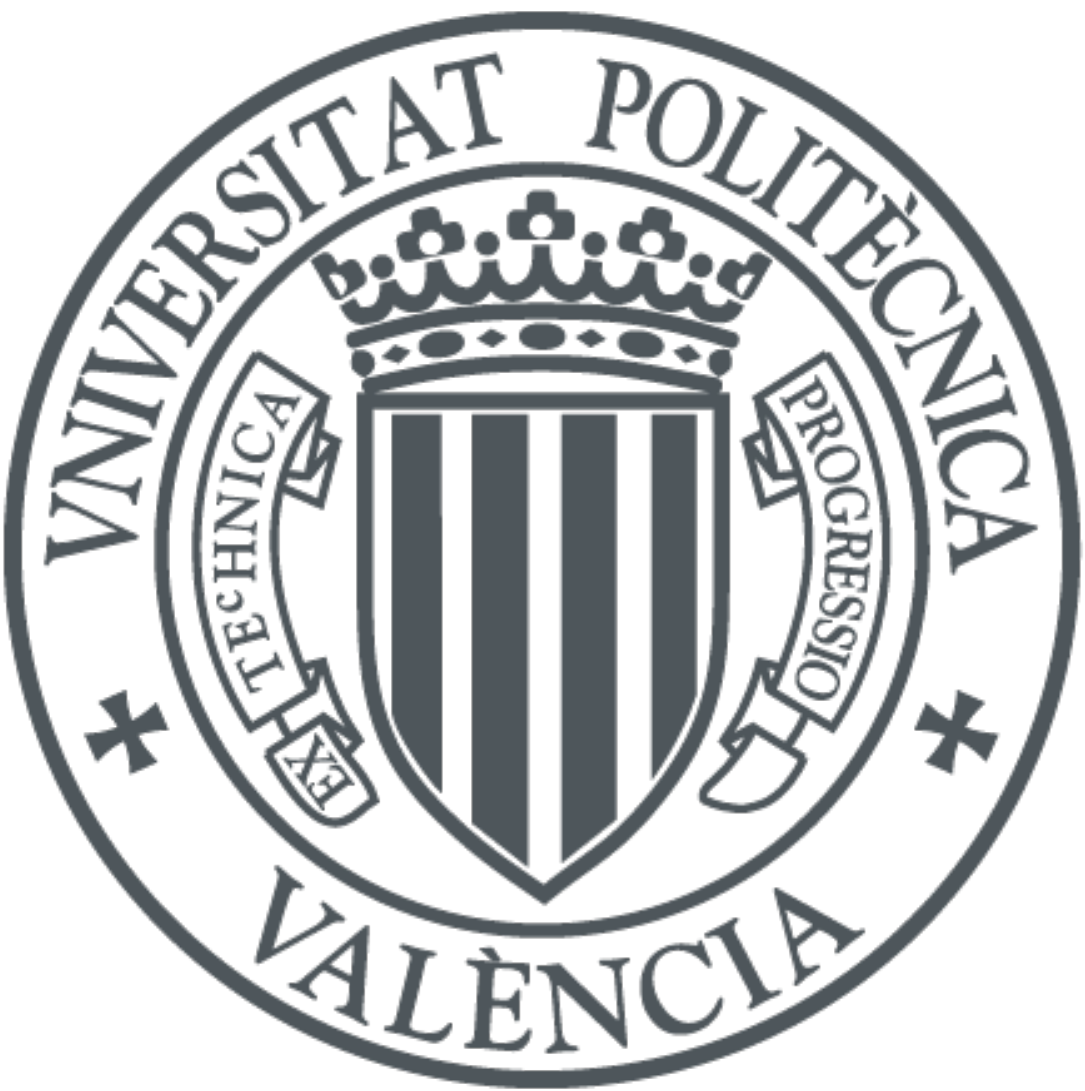

The final publication is available at

http://doi.org/10.2174/1385272822666171129153011

Copyright Bentham Science

Additional Information 


\title{
Biopolymers carrying essential oils, or their compounds, for food antimicrobial packaging
}

Raquel Requena ${ }^{\mathrm{a}}$, Maria Vargas ${ }^{\mathrm{a}}$, Lorena Atarés ${ }^{\mathrm{a}}$, Amparo Chiralt $\mathrm{t}^{\mathrm{*}}$

${ }^{a}$ Institute of Food Engineering for Development, Universitat Politècnica de València,. Spain

\begin{abstract}
Biodegradable antimicrobial materials for food packaging applications are in great demand by the food industry and society alike for the purposes of extending food shelf life, thus reducing the environmental impacts associated with synthetic plastics. Among the natural and non-toxic active compounds available, essential oils and their major components have been widely studied due to their antioxidant and antimicrobial properties together with their Generally Recognized as Safe status. In this review, the antimicrobial and antioxidant properties of several essential oils and their major compounds are summarized, as well as their action when included in different biopolymer-based matrices. Both the method of incorporating active ingredients into the biopolymer matrix and the yield of such processes as a function of the technique used (casting methods or thermoplastic processing) are also assessed. The effect of active compounds on the film's functional properties is reviewed, as well as the effective release of the active ingredients into different food systems and food simulants, as affected by polymer-active interactions and the nature of the food. Finally, the antimicrobial action of some of these active compounds (embedded in different biopolymer matrices) is also discussed both in in vitro studies and in antimicrobial tests performed using foods of different composition.
\end{abstract}

Keywords: Biopolymer, essential oil, antimicrobials, controlled release, food shelf life, mechanical properties, barrier properties.

\section{INTRODUCTION}

One of present-day society's challenges is to develop biodegradable active materials for food packaging applications in order to improve the shelf-life of food and, at the same time, reduce the environmental impacts associated with synthetic plastics. Biopolymers from different origins can be used for food packaging applications or food coating purposes, but the functional properties of biopolymer-based materials in terms of their mechanical and barrier properties need to be adapted to food requirements. To this end, numerous studies have been carried out applying different strategies to reduce the drawbacks of using biopolymers for packaging purposes. Polar biopolymers, such as starch, chitosan, cellulose derivatives or proteins, exhibited high water sensitivity and the water plasticization effects lead to a worsening of the mechanical and barrier properties. On the other hand, more hydrophobic matrices, such as biodegradable polyesters, exhibited brittleness and great oxygen permeability, which in turn limit their ability to control the oxidation reactions responsible for food deterioration. Of the different strategies used to adapt these materials to food packaging requirements, polymer blending with or without compatibilizers [1, 2], extrusion reaction using a catalyst to favour crosslinking [3] or multilayer films combining materials with complementary barrier properties, have been analysed [4].

Likewise, the incorporation of antimicrobial or/and antioxidant compounds into biopolymer-based materials is a good approach to obtain active films, with more competitive properties, useful to extend the shelf life of foodstuffs. The release kinetics of actives into different food systems need to be evaluated in order to analyze the effectiveness of these materials for food preservation, adapting them to specific target applications thus helping to enhance food quality and safety. Of the available natural and non-toxic active compounds, essential oils and their major components have been widely studied, due to their antioxidant and antimicrobial properties together with their Generally Recognized as Safe status.

In this review, the antimicrobial properties of several essential oils and their major compounds are summarized, as well as their action when included in different biopolymerbased matrices. Both the method of incorporating active ingredients into the biopolymer matrix and the yield of such processes, depending on the technique used (casting methods or thermoplastic processing), are also discussed. Likewise, the effect of active compounds on the film's functional properties is reviewed, as well as the factors affecting the effective release of the active ingredients into different food systems or food simulants, depending on the polymer-active interactions and the nature of the food. Finally, the antimicrobial action of some of these active compounds, embedded in different biopolymer matrices, when applied to foods of different composition is also discussed and compared with the results obtained in in vitro studies.

*Address correspondence to this author at the Institute of Food Engineering
for Development, Universitat Politècnica de València, P.O. Box: 46022,
Valencia, Spain; Tel/Fax: ++00-36-963877000, E-mail: dchiralt@tal.upv.es

\section{ANTIMICROBIAL PROPERTIES OF ESSENTIAL OILS OR THEIR COMPOUNDS}

The antimicrobial properties of plant ESs have been widely studied. Both EOs and several of their constituents represent a natural alternative to chemical food preservatives. EOs are complex in composition, being a 
source of bioactive compounds, such as terpenoids and phenolic compounds. It has long been recognized that EOs exhibit antioxidant [5, 6] and antimicrobial properties. Several antimicrobial mechanisms have been described to explain the action of EOs against microorganisms, namely membrane destabilization and disruption [7, 8]; the inhibition of membrane localized metabolic events [9, 10]; damage in the membrane proteins [11]; the depletion of proton motive force [12]; and the leakage of cytoplasmic constituents, metabolites and ions [13, 14]. Table 1 gives an overview of the current state of the art in this topic, showing some of the most recent and relevant studies dealing with the antimicrobial action of EOs and their major compounds. These studies reinforce the potential use of EOs and their major components as food preservatives due to their capacity to inhibit the growth of a wide variety of pathogenic and/or food-spoiling microorganisms.

Moreover, a synergistic effect between EOs and their major components has recurrently been observed in different studies. Ouedrhiri et al. [28] found that the antibacterial capacity of an EOs mixture (Origanum compactum, Origanum majorana and Thymus serpyllum) was greater than that of each essential oil, especially against $S$. Aureus and E. Coli. Ye et al. [33] concluded that cinnamaldehyde and carvacrol exhibit a high degree of antibacterial activity and display synergistic antimicrobial activity for most of the bacteria tested (Table 1).

Nonetheless, the concentrations of EOs or their individual constituents required to inhibit bacteria in foods are frequently higher than what is organoleptically acceptable $[35,36]$. Moreover, the highly volatile nature of these compounds, along with their great sensitivity to oxidation, which makes them prone to deterioration, limits their freeform application onto the surface of food systems. In an attempt to avoid this, what has been studied is the incorporation of EOs into the formulation of films and coatings. Table 2 summarizes recent studies of the antimicrobial activity of biopolymer films into which either EOs or their individual major compounds have been incorporated. A wide variety of EOs has been tested in different carrying biopolymers, and the in vitro studies, using the agar diffusion method, have proven their efficiency as antimicrobials. They mainly act against different bacteria, although they are also reported to exhibit antifungal activity $[5,50,58,61]$.

There have been fewer studies into real food systems, although several authors report an effective or limited antimicrobial action, depending on the kind of food matrix. For instance, Guerreiro et al. [52] incorporated eugenol and/or citral into alginate or pectine films, and proved their antimicrobial activity when applied to raspberries. However, Higueras et al. [62] could not find any notable antilisterial action of carvacrol on chicken breast, despite its proven effectiveness in in vitro studies. Interactions of active compounds and microorganisms were greatly affected by food components [63], as described below.

\section{INCORPORATION METHODS OF EOS OR THEIR COMPOUNDS INTO POLYMER MATRICES}

In order to develop biodegradable antimicrobial packaging systems incorporating EOs, the processability of the biopolymers and of the active ingredients should be taken into account. Casting methods or thermoplastic processing could be used to incorporate active compounds into the polymer matrices to obtain active biomaterials for packaging applications. Nevertheless, the former method has scarce industrial applicability because of the need to evaporate great amounts of solvent. In the case of aqueous systems, this is energetically non-sustainable and for organic solvents, the fact that they are toxic and dangerous to handle compromises their application. So, this kind of active compound incorporation is restricted to coating the surface of thermo-processed films with a thin layer of the active solution and carrier. Then, smaller amounts of solvent need to be evaporated, thus enhancing the process feasibility. However, the solvent casting method has been widely used to obtain biopolymer active matrices that incorporate essential oils or their compounds, at a laboratory level, for the purposes of obtaining the functional properties of the biopolymer matrices and their potential use as antimicrobial/antioxidant materials [57, 64, 65]. Casting methods involve solving the biopolymer in an appropriate medium and adding the active ingredient under continuous stirring conditions. When using aqueous media and hydrophilic biopolymers, the solvent-polymer-EO mixture forms immiscible systems (emulsions) and requires a high degree of homogenization to achieve a good dispersion with small droplets. Rotor-stator homogenizers, sonication [66] or microfluidization [65] has been used to this end. The latter can increase the stability of the film-forming dispersion by reducing its particle size. Finally, to obtain the active matrices, the dispersion containing the active ingredients is cast in a levelled plate and is allowed to dry under controlled conditions.

The casting/solvent evaporation method exhibits some advantages for the incorporation of active ingredients, but also significant drawbacks, depending on the nature of the polymer (polar or non-polar), its solubility in different solvents and the chemical affinity between the polymer, EO compounds and solvent. Hydrophobic non-polar biopolymers, such as biodegradable polyesters (like polylactic acid: PLA) have to be solved in non-polar organic solvents, such as dichloromethane (DCM) or chloroform, which require special precautions during film processing and the use of a fume hood. In these cases, the EO compounds gain solubility and true solutions of the macromolecules and active compounds can be obtained.

Notable differences in films' microstructure and losses of EO can be found in films obtained by casting method, depending on the polymer and solvent polarity, and aqueous and non-polar systems can be differentiated. Figure 1 shows the cross section of a chitosan film where droplets of the non-miscible cinnamon EO are embedded in the polymer matrix, introducing discontinuities which affect both the mechanical behaviour and mass transfer phenomenon through the film. On the other hand, essential oil compounds encapsulated in lecithin liposomes produced a laminar structure in chitosan films in line with the restructuration (phase transition) of the lecithin during the film drying step 
Table 1: Recent studies on the antimicrobial action of essential oils and their major compounds. Minimal inhibitory concentration (MIC) ranges have been included.

\begin{tabular}{|c|c|c|c|}
\hline EO & Microorganisms tested & MIC & Reference \\
\hline $\begin{array}{l}\text { Myrcia ovata } \\
\text { Cambessedes }\end{array}$ & $\begin{array}{l}\text { Pseudomonas aeruginosa, Staphylococcus aureus, Bacillus } \\
\text { cereus, Bacillus subtilis, Enterecoccus faecalis, Serratia } \\
\text { marcescens, Escherichia coli, Salmonella enteritidis }\end{array}$ & $0.78-400 \mu \mathrm{l} / \mathrm{ml}$ & [15] \\
\hline $\begin{array}{l}\text { Etlingera } \\
\text { fimbriobracteata }\end{array}$ & $\begin{array}{l}\text { Bacillus subtilis, Bacillus spizizenii., Staphylococcus aureus, } \\
\text { Escherichia coli, Pseudomonas aeruginosa, Candida } \\
\text { albicans, Saccharomyces cerevisiae }\end{array}$ & $0.15-625 \mu \mathrm{g} / \mathrm{ml}$ & [16] \\
\hline $\begin{array}{l}\text { Bergamot-mint } \\
\text { (Mentha citrata) }\end{array}$ & $\begin{array}{l}\text { Staphylococcus aureus, Staphylococcus epidermidis, } \\
\text { Streptococcus mutans, Klebsiella pneumoniae, Escherichia } \\
\text { coli, Salmonella typhimurium, Pseudomonas aerugenosa }\end{array}$ & $125->1000 \mu \mathrm{g} / \mathrm{ml}$ & [17] \\
\hline Cinnamon bark & \multirow[t]{2}{*}{ L. monocytogenes, Salmonella enterica and E. coli O157:H7 } & 313-625ppm & [18] \\
\hline Thyme & & 313-625ppm & [18] \\
\hline Eucalyptus globulus & S. aureus, B. subtilis, L. innocua, E. coli, P. aerugenosa & $3-5 \mathrm{mg} / \mathrm{ml}$ & [19] \\
\hline Thymus & $\begin{array}{l}\text { Penicillium digitatum, Penicillium italicum and Geotrichum } \\
\text { citri-aurantii }\end{array}$ & $<500->4000 \mu \mathrm{g} / \mathrm{ml}$ & [20] \\
\hline Mustard & \multirow{2}{*}{ 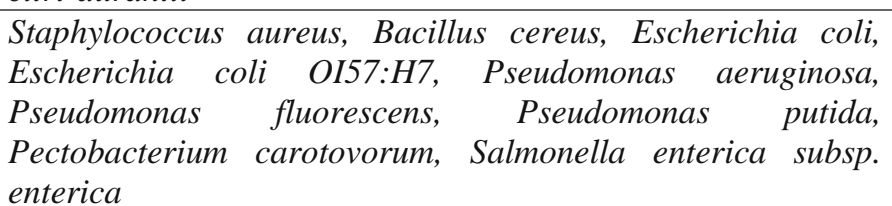 } & $12.5-200 \mu \mathrm{g} / \mathrm{ml}$ & [21] \\
\hline Cinnamon & & $200-400 \mu \mathrm{g} / \mathrm{ml}$ & [21] \\
\hline Origanum vulgare & $\begin{array}{l}\text { Staphylococcus aureus, Escherichia coli, Sarcina lutea, } \\
\text { Bacillus cereus, Pseudomonas aeruginosa, Salmonella } \\
\text { typhimurium, Enterococcus faecalis, Candida albicans }\end{array}$ & $85->512 \mu \mathrm{g} / \mathrm{ml}$ & [22] \\
\hline $\begin{array}{l}\text { Mentha x piperita } \\
\text { L. }\end{array}$ & \multirow{5}{*}{$\begin{array}{l}\text { Streptococcus pyogenes, Streptococcus mutans, Lactobacillus } \\
\text { acidophilus, Streptococcus salivarius, Streptococcus sangunis, } \\
\text { Enterecoccus feacalis, Pseudomonas aeruginosa, } \\
\text { Staphylococcus aureus }\end{array}$} & $238-1125 \mu \mathrm{g} / \mathrm{ml}$ & [23] \\
\hline $\begin{array}{l}\text { Mentha pulegium } \\
\text { L. }\end{array}$ & & $593-1192 \mu \mathrm{g} / \mathrm{ml}$ & [23] \\
\hline $\begin{array}{l}\text { Lavandula } \\
\text { angustifolia Mill. }\end{array}$ & & $160-2333 \mu \mathrm{g} / \mathrm{ml}$ & [23] \\
\hline $\begin{array}{l}\text { Satureja montana } \\
\text { L. }\end{array}$ & & $23-125 \mu \mathrm{g} / \mathrm{ml}$ & [23] \\
\hline $\begin{array}{l}\text { Salvia } \\
\text { lavandulifolia Vahl }\end{array}$ & & $2901208 \mu \mathrm{g} / \mathrm{ml}$ & [23] \\
\hline Thymus numidicus & \multirow{2}{*}{$\begin{array}{l}\text { Staphylococcus aureus, Klebsiella pneumoniae, Escherichia } \\
\text { coli, Serratia marcescens, Pseudomonas aeruginosa }\end{array}$} & $0.117-0.469 \mathrm{mg} / \mathrm{ml}$ & [24] \\
\hline Salvia officinalis L., & & $3.7-15 \mathrm{mg} / \mathrm{ml}$ & [24] \\
\hline Lime & $\begin{array}{l}\text { E. coli, S. typhinurium, B. cereus, S. } \begin{array}{l}\text { aureus, } \\
\text { monocytogenes }\end{array}\end{array}$ & $750-1500 \mathrm{mg} / \mathrm{l}$ & [25] \\
\hline Cinnamon & $\begin{array}{l}\text { L. monocytogenes, E. coli, Ps. Fluorescens, L. plantarum, L. } \\
\text { sakei }\end{array}$ & 250-500ppm & [26] \\
\hline $\begin{array}{l}\text { Satureja montana } \\
\text { L. }\end{array}$ & \multirow[t]{3}{*}{ Salmonella } & $0.39-0.78 \mathrm{mg} / \mathrm{ml}$ & [27] a \\
\hline Thymus vulgaris $L$ & & $0.78-1.56 \mathrm{mg} / \mathrm{ml}$ & [27] \\
\hline $\begin{array}{l}\text { Rosmarinus } \\
\text { officinalis } L \text {. }\end{array}$ & & $12.5-25 \mathrm{mg} / \mathrm{ml}$ & [27] \\
\hline $\begin{array}{l}\text { Origanum } \\
\text { compactum }\end{array}$ & \multirow[t]{3}{*}{$\begin{array}{l}\text { Staphylococcus aureus, Escherichia coli, Bacillus subtilis, } \\
\text { Pseudomonas aeruginosa }\end{array}$} & $0.031->4 \%(\mathrm{v} / \mathrm{v})$ & [28] \\
\hline $\begin{array}{l}\text { Origanum } \\
\text { majorana }\end{array}$ & & $0.125-2 \%(\mathrm{v} / \mathrm{v})$ & [28] \\
\hline Thymus serpyllum & & $0.125->4 \%(\mathrm{v} / \mathrm{v})$ & [28] \\
\hline Rosmarinus & C. perfringens & $10 \mathrm{mg} / \mathrm{ml}$ & [29] \\
\hline
\end{tabular}




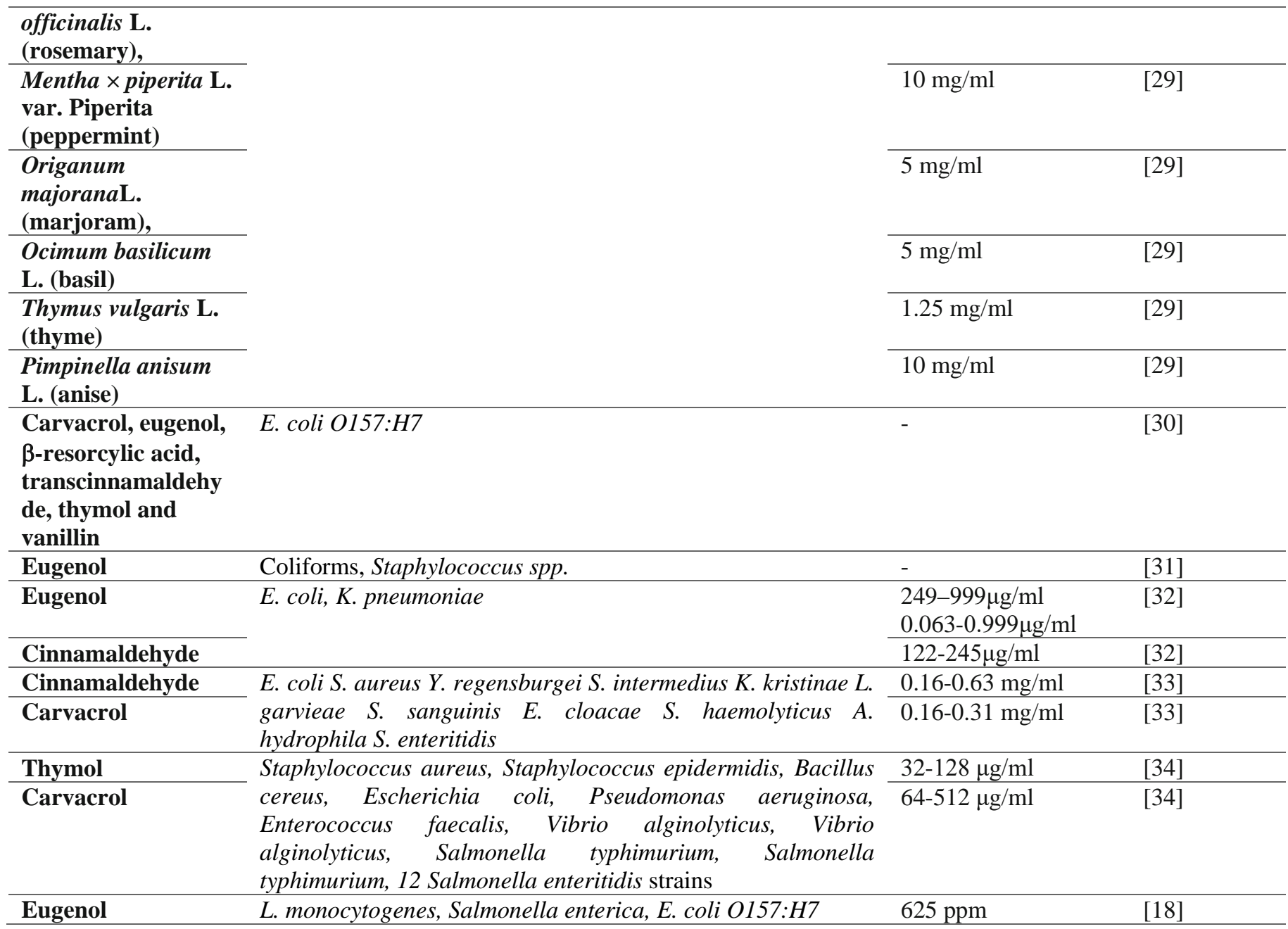

Table 2: Recent studies on the antimicrobial action of essential oils and their major components embedded in biopolymer matrices. In vitro test (IVT) in culture media or in different food systems have been included.

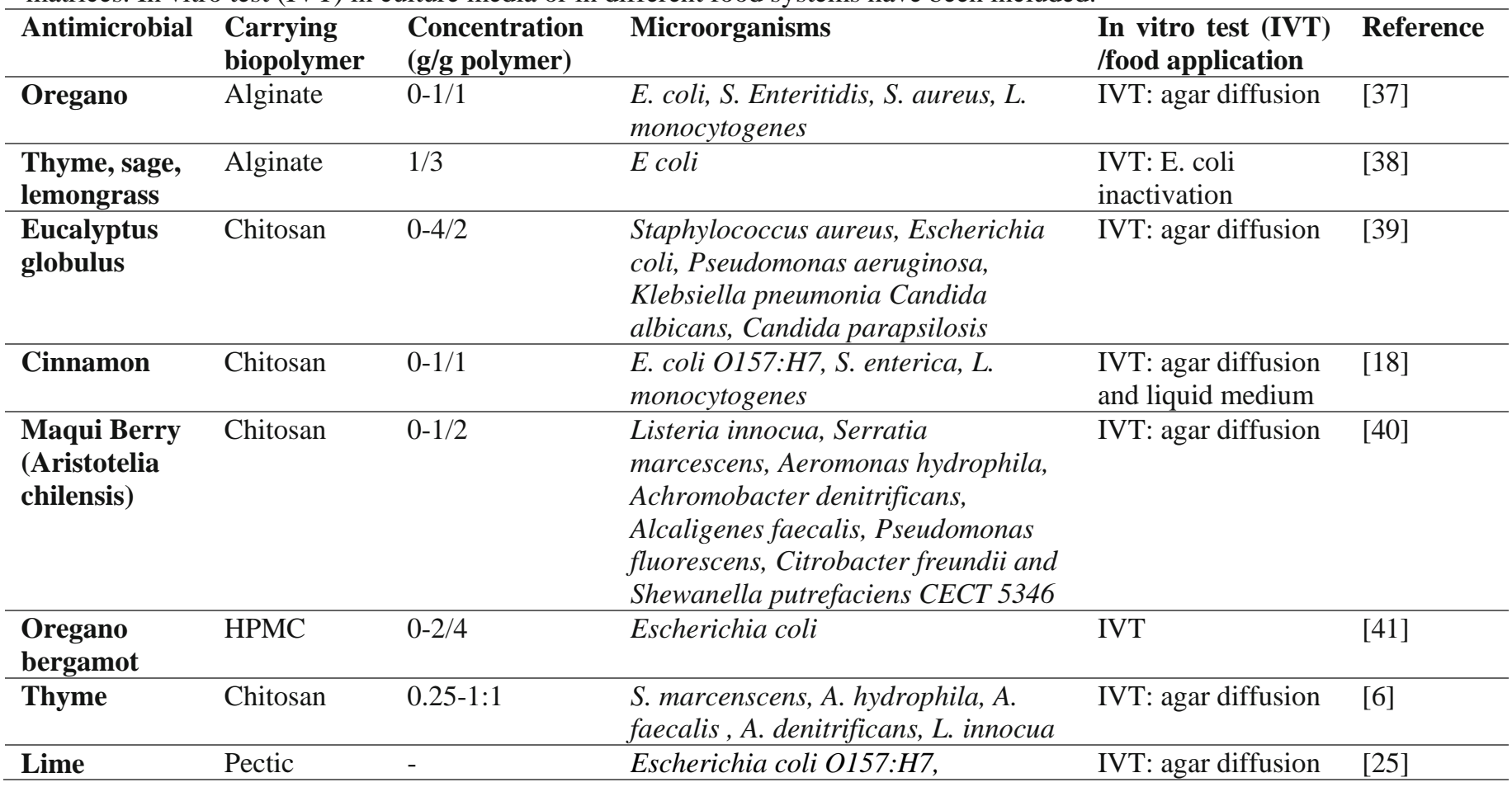




\begin{tabular}{|c|c|c|c|c|}
\hline & extract & & $\begin{array}{l}\text { Salmonella Typhimurium, } \\
\text { Staphylococcusaureus, Bacillus } \\
\text { cereus and Listeria monocytogenes }\end{array}$ & \\
\hline Cinnamon & Chitosan & $0.4-2 / 2$ & $\begin{array}{l}\text { L. monocytogenes, E. coli, L. } \\
\text { plantarum, L. sakei, P. fluorescens }\end{array}$ & IVT: agar diffusion [26] \\
\hline Oregano & Mucilage & $0-2 / 35$ & $\begin{array}{l}\text { L. monocytogenes, Salmonella } \\
\text { typhimurium, Bacillus cereus, } \\
\text { Yersinia enterocolitica, Pseudomonas } \\
\text { aeruginosa, S. aureus, E. coli, E. coli } \\
\text { O157:H7, Shewanella } \\
\text { putrefaciens, and Vibrio cholera }\end{array}$ & IVT: agar diffusion [42] \\
\hline $\begin{array}{l}\text { Matricaria } \\
\text { recutita }\end{array}$ & $\begin{array}{l}\text { Sodium } \\
\text { caseinate }\end{array}$ & $1 / 5$ & $\begin{array}{l}\text { Listeria monocytogenes, S. aureus } \\
\text { and E. coli O157:H7 }\end{array}$ & IVT: agar diffusion [43] \\
\hline $\begin{array}{l}\text { Clove, fennel, } \\
\text { cypress } \\
\text { lavender, } \\
\text { thyme herb- } \\
\text { of-the-cross, } \\
\text { pine and } \\
\text { rosemary }\end{array}$ & $\begin{array}{l}\text { Gelatin } \\
\text { alone or with } \\
\text { chitosan }\end{array}$ & $0.75 / 1$ & $\begin{array}{l}\text { P. fluorescens, L. acidophilus, } L \text {. } \\
\text { innocua, E. coli. }\end{array}$ & $\begin{array}{l}\text { IVT agar diffusion } \\
\text { and application on } \\
\text { fish }\end{array}$ \\
\hline $\begin{array}{l}\text { Citronella, } \\
\text { coriander, } \\
\text { tarragon, } \\
\text { thyme }\end{array}$ & Hake protein & $0.25 / 1$ & $\begin{array}{l}\text { B. thermosphacta, E. coli, L. innocua, } \\
\text { L. monocytogenes, } P \text {. putida, S. } \\
\text { typhimurium, S. putrefaciens }\end{array}$ & IVT: agar diffusion [45] \\
\hline $\begin{array}{l}\text { Oregano, } \\
\text { bergamot }\end{array}$ & HPMC & $0-0.1 / 1$ & E. coli & $\begin{array}{l}\text { Application on } \\
\text { plums }\end{array}$ \\
\hline $\begin{array}{l}\text { Thyme, } \\
\text { oregano }\end{array}$ & Soy protein & $0-5 / 5$ & $\begin{array}{l}\text { S. aureus, E.coli, } P \text {. aeruginosa, L. } \\
\text { plantarum, total viable, lactic acid } \\
\text { bacteria, Staphilococcus spp, } \\
\text { coliforms, Pseudomonas spp }\end{array}$ & $\begin{array}{l}\text { IVT: agar diffusion } \\
\text { and application on } \\
\text { beef patties }\end{array}$ \\
\hline Lemon & Chitosan & $3 / 1$ & Botrytis cinerea & $\begin{array}{l}\text { IVT and application } \\
\text { on strawberry }\end{array}$ \\
\hline Bergamot & $\begin{array}{l}\text { HPMC, } \\
\text { chitosan }\end{array}$ & $2 / 1$ & $\begin{array}{l}\text { Total aerobic mesophilic } \\
\text { microorganisms, yeast and mould }\end{array}$ & $\begin{array}{l}\text { Application on } \\
\text { grapes }\end{array}$ \\
\hline $\begin{array}{l}\text { Bergamot, } \\
\text { lemon, tea } \\
\text { tree }\end{array}$ & $\begin{array}{l}\text { HPMC, } \\
\text { chitosan }\end{array}$ & $0-3 / 1$ & E. coli, L. monocytogenes, S. aureus & IVT \\
\hline Bergamot & Chitosan & $0-3 / 1$ & P. italicum & IVT \\
\hline Tea tree & Chitosan & $0-2 / 1$ & $\begin{array}{l}\text { Penicillium italicum, } L . \\
\text { monocytogenes }\end{array}$ & IVT \\
\hline $\begin{array}{l}\text { Citral and } \\
\text { eugenol }\end{array}$ & $\begin{array}{l}\text { Alginate and } \\
\text { pectin }\end{array}$ & $0.05-0.15 / 1$ & Moulds and yeast, aerobic mesophilic & $\begin{array}{l}\text { Application on } \\
\text { raspberry }\end{array}$ \\
\hline $\begin{array}{l}\text { Cinnamaldeh } \\
\text { yde }\end{array}$ & $\begin{array}{l}\text { PLA and } \\
\text { PCL }\end{array}$ & $9 / 1$ & $\begin{array}{l}\text { Mesophilic and psychrophilic } \\
\text { bacteria }\end{array}$ & $\begin{array}{l}\text { Application on } \\
\text { mushrooms }\end{array}$ \\
\hline Thymol & Starch & - & $\begin{array}{l}\text { Listeria monocytogenes, Salmonella } \\
\text { Typhimurium }\end{array}$ & $\begin{array}{l}\text { Application on } \\
\text { cantaloupe juice }\end{array}$ \\
\hline $\begin{array}{l}\text { Cinnamaldeh } \\
\text { yde }\end{array}$ & PLA & $0.02 / 0.8$ & E. coli, Bacillus cereus & IVT \\
\hline $\begin{array}{l}\text { Mandarin, } \\
\text { lemon, sweet } \\
\text { orange, } \\
\text { hybrid of } \\
\text { Oroval } \\
\text { clementine x } \\
\text { Tarocco } \\
\text { orange }\end{array}$ & $\begin{array}{l}\text { Chitosan, } \\
\text { methylcellul } \\
\text { ose }\end{array}$ & $1 / 2$ & Listeria monocytogenes & IVT \\
\hline Chitosan & Basil, thyme & $0-0.5 / 1$ & $\begin{array}{l}\text { Aspergillus niger, B. cinerea, } R . \\
\text { stolonifer }\end{array}$ & [57] \\
\hline Chitosan & $\begin{array}{l}\text { Cinnamon } \\
\text { leaf }\end{array}$ & $0-0.5 / 1$ & $\begin{array}{l}\text { Aspergillus niger,Botrytis cinerea, } \\
\text { Rhizopus stolonifer }\end{array}$ & $\begin{array}{l}\text { IVT and application [58] } \\
\text { on strawberry }\end{array}$ \\
\hline
\end{tabular}




\begin{tabular}{llllll}
\hline $\begin{array}{l}\text { Starch- } \\
\text { gelatin blend }\end{array}$ & $\begin{array}{l}\text { Oregano, } \\
\text { clove, } \\
\text { cinnamon } \\
\text { bark }\end{array}$ & $0-0.25 / 1$ & $\begin{array}{l}\text { Colletotrichum gloesporoides, } \\
\text { Fusarium oxysporum f.sp. gladiolo }\end{array}$ & IVT & [59] \\
\hline Chitosan & $\begin{array}{l}\text { Eugenol, } \\
\text { cinnamon } \\
\text { leaf }\end{array}$ & $0.476 / 1$ & Escherichia coli & IVT & {$[60]$} \\
\hline
\end{tabular}

[60]. During this step, the water loss induced the lamellar structure of the polar lipids, which alternates with the polymer layers giving rise to a high barrier material containing EO compounds inside lipid layers. On the contrary, a smooth fracture can be appreciated in PHBV films containing eugenol, due to its good miscibility with the polymer. In this way, eugenol plasticized the matrix and also affected the tensile and barrier properties due to the weakening effect on the polymer network. In semi crystalline matrices, these compounds can also affect the degree of crystallinity [67].
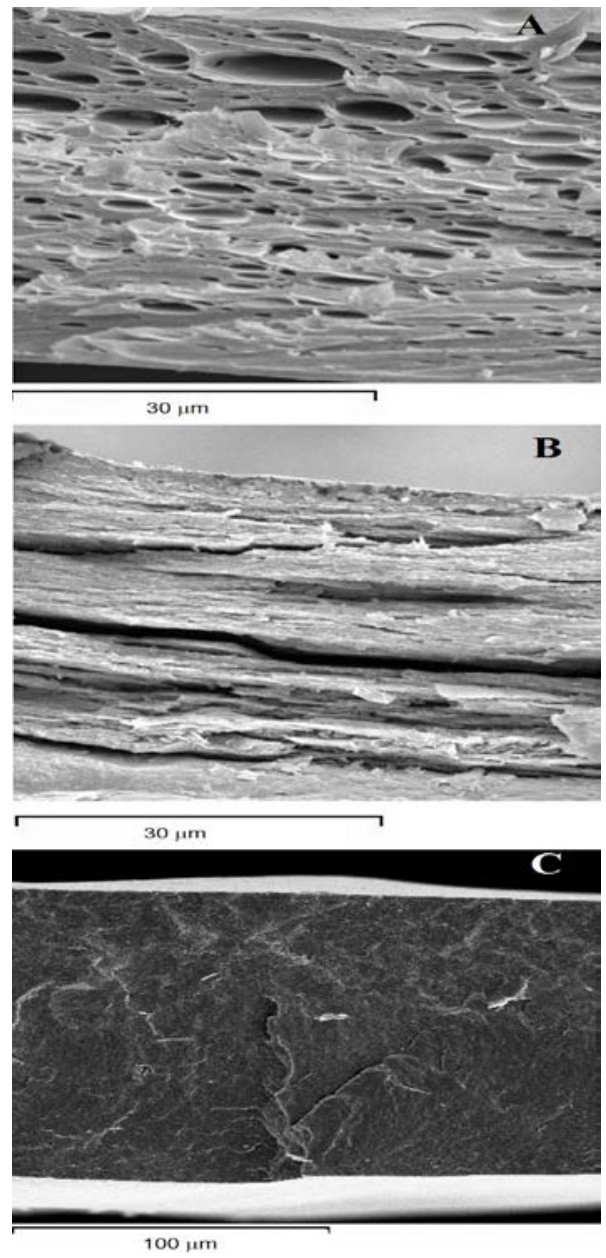

Figure 1. The film microstructure of different biopolymers containing EOs, or some of their compounds, obtained by different techniques. A: chitosan-cinnamon leaf EO film, obtained by casting. B: chitosan-lecithin encapsulated eugenol film, obtained by casting. C: PHBV-Eugenol, obtained by compression moulding.
On the other hand, using aqueous solvents leads to significant losses of the EO compounds due to a steam distillation effect at surface level during the film drying step. Throughout this step, EO droplets flocculate, coalesce and cream to the top of the drying film to a different extent, where EO compounds volatilize together with water. In this way, particular constituents of the EO are lost depending on their relative amount in the oil. In an aqueous solvent, the major compounds can lose over $50 \%$ of the EO added to the film-forming dispersion, depending on the emulsion stability and the total lipid creaming during film drying. Smaller droplets, higher surface particle charge and the interfacial adsorption of amphiphilic molecules, such as proteins or surfactants, enhanced emulsion stability and reduced the losses of EO during film drying [57]. Micro and nanoencapsulation of EO compounds before film preparation could be a way to minimize this problem and improve the effectiveness of active packaging containing essential oils. In this sense, the use of liposomes or nanoliposomes, which can act as carrier systems of a wide range of compounds, represent an interesting alternative [68]. Cyclodextrins have also been very effective at entrapping ES compounds when they are incorporated into the polymer matrices. A high ratio of carvacrol could be adsorbed in chitosan films containing cyclodextrins, depending on their glycerol and moisture content, when the films are immersed in the compound (the so-called nanosponges) [69].

Table 3 shows some examples of different methods used to incorporate essential oils into biopolymer matrices in order to develop antimicrobial packaging concepts. Materials produced by thermoplastic techniques that are used industrially for the purposes of processing synthetic plastics are usually dry mixed and afterwards extruded or melt blended to obtain thermoformable packaging products.

In the first step, the biopolymer is blended with the plasticizing additives and the active ingredients by using a hot mixer. The mixing temperature depends on the melting point of the biopolymer. Blending temperatures of $155^{\circ} \mathrm{C}$ and $80^{\circ} \mathrm{C}$ have been used for PLA and polycapralactone (PCL), respectively [83]. In the second step, also performed at the mixing temperature and at high pressure, a hot-plate hydraulic press can be used to obtain films or samples that are suitable for extrusion. EO compounds can also be incorporated in different zones of the screw in an extruder after polymer melting. Recently, Requena et al. [67] have shown that the use of spraying to incorporate EOs at the interface of two thermoplastic films and the subsequent thermo-compression of the films, could be an appropriate strategy with which to improve the process of obtaining active films containing EO and reduce the loss of active compounds. 
Table 3. Incorporation methods of essential oils (EO) or EO compounds into biopolymer matrices.

\begin{tabular}{|c|c|c|c|}
\hline Method & EO/Compound & Biopolymer & Reference \\
\hline \multicolumn{4}{|c|}{ 1.CASTING METHODS } \\
\hline Dissolution in DCM & Cinnamon EO & PLA & {$[70]$} \\
\hline \multirow[t]{5}{*}{ Dissolution in chloroform } & Oregano EO & PLA & [71] \\
\hline & Cinnamaldehyde & PLA/PCL & [53] \\
\hline & Oregano EO & PLA-CNC & [72] \\
\hline & Cinnamaldehyde, allyl isothiocyanate, & PCL & [73] \\
\hline & Eugenol & PHB & [74] \\
\hline Dissolution in ethanol & Thymol & Zein & [75] \\
\hline Emulsification in distilled water & Cinnamon EO & Agar/Alginate & {$[76]$} \\
\hline $\begin{array}{l}\text { Encapsulation with cyclodextrin } \\
\text { and water dispersion }\end{array}$ & Eugenol and carvacrol & WPI & {$[77]$} \\
\hline $\begin{array}{l}\text { Encapsulation with soy oil and } \\
\text { alginate and dispersion in aqueous } \\
\text { medium }\end{array}$ & Lemongrass EO & Sodium alginate & {$[78]$} \\
\hline $\begin{array}{l}\text { Encapsulation in soy lecithin } \\
\text { liposomes and dispersion in } 1 \% \\
\text { aqueous acetic acid }\end{array}$ & Cinnamon leaf EO, eugenol & Chitosan & [60] \\
\hline $\begin{array}{l}\text { Dispersion in } 1 \% \text { aqueous acetic } \\
\text { acid }\end{array}$ & $\begin{array}{l}\text { Bergamot, oregano, basil, clove, EO, } \\
\text { carvacrol }\end{array}$ & Chitosan & {$[48,58,65,79]$} \\
\hline \multicolumn{4}{|c|}{ 2. THERMOPLASTIC PROCESSING } \\
\hline $\begin{array}{l}\text { Melt blending and compression } \\
\text { moulding }\end{array}$ & Thyme EO & Wheat gluten & {$[80]$} \\
\hline Melt blending and extrusion. & Thymol & PBS & [81] \\
\hline $\begin{array}{l}\text { Melt blending and compression } \\
\text { moulding }\end{array}$ & Thymol & PLA & {$[82]$} \\
\hline $\begin{array}{l}\text { Spraying between } \\
\text { thermocompressed layers plus } \\
\text { thermo- compression }\end{array}$ & $\begin{array}{l}\text { Oregano EO, carvacrol, clove EO, } \\
\text { eugenol }\end{array}$ & PHBV & [67] \\
\hline
\end{tabular}

During thermal processing, a part of the EO compounds can evaporate or decompose, depending on the thermal conditions and their respective volatility and thermostability. The encapsulation of essential oils with compounds, such as cyclodextrins, can protect active ingredients against evaporation and thermal degradation, thus minimizing their loss. Cyclodextrins, which are starch derivatives with a ringed structure, are able to form inclusion complexes with volatile compounds that are held tight within the molecular structure of the cyclodextrins [84]. Loaded cyclodextrins with trans-2-hexenal were included in PLA matrices by extrusion in order to obtain antimicrobial sheets, which exhibited antifungal activity against several food spoilage fungi, despite the significant losses of antimicrobials occurring during thermal processing [85]. Likewise, Wen et al [86] incorporated cinnamon essential oil/beta cyclodextrin inclusion complex into PLA nanofibers via electrospinning technique. The thermal stability of cinnamon essential oil in the PLA matrix was significantly improved due to strong interactions between beta cyclodextrin and the essential oil. Moreover, the electrospun nanofilm showed antimicrobial activity against both Gram-positive and Gram-negative bacteria, and prolonged the shelf-life of pork meat stored at $25^{\circ} \mathrm{C}$.

\section{IMPACT OF EOS ON THE FILM FUNCTIONAL PROPERTIES.}

The EO compounds in the polymer matrices have different effects on the functional properties of the materials used for packaging purposes. The discontinuities in the matrix (droplets) or the weakening of chain interactions can provoke changes in the mechanical resistance and barrier capacity of the materials, depending on the film's microstructure and the interactions between compounds and biopolymer.

\subsection{Barrier properties}

Being mainly hydrophobic mixtures/compounds, EOs may be expected to improve the water barrier properties of biopolymer films, which are frequently based on hydrophilic materials, such as carbohydrates and proteins. This trend has been observed in several studies, as reported in Table 4 . However, the opposite trend has also been repeatedly reported (Table 4), which suggests that the hydrophobichydrophilic balance is not the only factor to be taken into account when aiming to explain the effect of EOs on the barrier properties of biopolymer films. Essential oil incorporation in hydrophilic film matrices, such as polysaccharides or proteins, implies the occurrence of a dispersed phase disrupting the matrix homogeneity, and 
giving rise to an emulsified film. In fact, the water vapour transfer phenomena through the biopolymer films is strongly dependent on the droplet size distribution in heterogeneous matrices. This, in turn, is mainly determined by the initial droplet size of the film forming aqueous dispersion, under determined homogenization conditions, and the emulsion destabilization phenomena taking place during the film drying step. Other factors, such as the physical state of the lipid and the interactions with the matrix, also play an important role. Fine lipid droplets, homogenously distributed in the film matrix, are most effective as water permeability reducers [94], since the high tortuosity factor in the continuous phase creates a great resistance to mass transfer. However, interactions of the EO compounds with the polymer chains may also limit chain aggregation in the film, leading to more open polymer matrices with less mass transfer resistance [65, 95].

In less polar polymer systems, such as biodegradable polyesters, the EO compounds are more miscible and usually act as plasticizers, thus promoting all of the diffusion dependent phenomena, such as water vapour or gas permeation [67]. The balance of the different effects determines the final influence of EO incorporation on the barrier properties of the biopolymer. In some cases, EO incorporation does not have a significant effect on the barrier properties of the films [41].

In general, the incorporation of EOs into the film matrix has been found to increase gas permeation. This can be mainly attributed to the greater solubility of gas molecules in the matrix, associated with the presence of more hydrophobic compounds. When EOs are incorporated, a lipid dispersed phase occurs in hydrophilic polymers, while hydrophobic matrices become more plasticized. Therefore, an increase in the gas permeability may be expected. As summarized in Table 4, this trend has been reported for several polymer-EO systems. However, as concerns oxygen permeability, films containing EOs or their compounds exhibit reduced values; this has been attributed to their antioxidant activity, which can exert an oxygen scavenging effect in the films [96, 97].

\subsection{Mechanical properties}

As regards the effect of EO incorporation into biopolymer films, the most frequently reported trend is a reduction in both the Elastic Modulus (EM) and Tensile Strength (TS) (Table 5), respectively associated with film stiffness and strength. The incorporation of EO into the polymer structure leads to the partial replacement of the stronger interactions between the polymer chains by weaker polymer-oil interactions [51, 89], thus allowing for the occurrence of structural discontinuities which reduce the mechanical resistance of the emulsified structure in hydrophilic matrices, where films tend to become less resistant to fracture and less stretchable. In hydrophobic matrices, the better compound compatibility leads to polymer plasticization, reducing both stiffness and strength, but enhancing the film extensibility.
Opposite behaviour can occur for particular EO-polymer blends where specific interactions are given. In fact, several studies have reported a strengthening effect as a result of the cinnamon EO incorporation in soy protein or chitosan matrices [26, 98]. In these cases, EO induces the rearrangement of the polymer network and some compounds provoke chain cross-linking, thereby improving the tensile properties [99]. Consisting of numerous chemical compounds with different molecular structures, EOs could interact with the polymer matrix differently. They also affect the film-water interactions, which also play a key role in mechanical behaviour. Otoni et al. [88] obtained soy protein films with carvacrol or cinnamaldehyde and observed a strengthening effect, which was explained by the reduction in the water adsorption capacity of the films, thus limiting their plasticizing action and making these films stiffer, under determined conditions of relative humidity.

\section{RELEASE OF EO FROM THE POLYMER MATRICES INTO FOOD OR FOOD SIMULANTS.}

The development of active packaging involves not only the incorporation of antimicrobial and/or antioxidant substances into the materials, but also the controlled release of the active compounds so as to maintain an effective concentration in the foodstuff over a period of time [82, 100]. In this sense, migration studies are required in order to determine the release rate of the actives from the film into the packaged food. In general, these studies are carried out in food simulants, which are liquid systems, which emulate the different hydrophilic or lipophilic nature of real foodstuffs. These have been standardized to find out how the different factors influence the migration process and to compare the behaviour of different active compounds and polymer matrices in distinct types of more or less hydrophilic foods. Aqueous food with neutral or acid $\mathrm{pH}$ can be properly simulated with distilled water containing $10-50 \%$ ethanol or $3 \%$ acetic acid, whereas $95 \%$ aqueous ethanol, oil or isooctane can be used to simulate fatty foodstuffs $[101,102]$.

Three coupled mechanisms are involved in the release mass transfer process: the diffusion of the food components (mainly water) into the polymer matrix, the relaxation of the macromolecular network, associated with the compound diffusion, and the diffusion of the active compound through the polymer. These mechanisms are coupled to a different extent until the thermodynamic equilibrium between film and food system phases is reached. Different models have been used to describe compound release kinetics, such first order kinetics and Fickian [103] or Peppas equations [104, 105]. Parameters that quantify the amount of compound released at equilibrium, and its release rate, are a useful means of understanding the extent to which the release takes place and to predict its effectiveness as an active. As concerns the delivery rate of actives, constant rate values (k) 
Table 4: Barrier properties (water vapor -WVP- and oxygen -OP- Permeability are commented) of biopolymer films as affected by the presence of EO.

\begin{tabular}{|c|c|c|c|c|c|}
\hline Matrix & EO & $\begin{array}{l}\text { Concentration } \\
\text { (g/g polymer) }\end{array}$ & $\begin{array}{l}\text { Main observations on the } \\
\text { incorporation }\end{array}$ & fect of EO & Reference \\
\hline HPMC & Oregano, bergamot & $0-0.1 / 1$ & $\begin{array}{l}\text { WVTR was not } \\
\text { significantly affected }\end{array}$ & $\begin{array}{l}\text { OTR increased } \\
\text { coherently with EO } \\
\text { proportion }\end{array}$ & [41] \\
\hline HPMC & $\begin{array}{l}\text { Plai, ginger, } \\
\text { fingerroot }\end{array}$ & - & WVP upward trend & OP upward trend & [87] \\
\hline Soy protein & $\begin{array}{l}\text { Carvacrol, } \\
\text { cinnamaldehyde }\end{array}$ & $0.67 / 10$ & WVP upward trend & - & [88] \\
\hline Lignocellulose & Cedarwood & $0-0.2 / 1$ & WVP was reduced & - & [89] \\
\hline $\begin{array}{l}\text { Fish gelatin } \\
\text { and chitosan }\end{array}$ & Origanum vulgare & $0.4-1.2 \% / 1.75 \%$ & $\begin{array}{l}\text { WVP increased coherently } \\
\text { with EO proportion }\end{array}$ & - & [90] \\
\hline Gelatin & Oregano, lavender & $0.04-0.12 / 1$ & $\begin{array}{l}\text { WVP not affected by } \\
\text { oregano, reduced by } \\
\text { lavender }\end{array}$ & - & [91] \\
\hline Alginate & $\begin{array}{l}\text { Thyme, } \\
\text { lemongrass, sage }\end{array}$ & $1 / 3$ & $\begin{array}{l}\text { WVP downward trend or } \\
\text { reduction }\end{array}$ & - & [38] \\
\hline Whey protein & Almond, walnut & $0.5-1 / 8$ & WVP was reduced & OP was increased & [92] \\
\hline Mucilage & Oregano & $0-2 / 35$ & WVP was increased & OP was increased & [42] \\
\hline Alginate & Oregano & $0-1 / 1$ & WVP was reduced & - & [37] \\
\hline Chitosan & Lemon & $3 / 1$ & WVP was reduced & - & [47] \\
\hline $\begin{array}{l}\text { HPMC, } \\
\text { chitosan }\end{array}$ & $\begin{array}{l}\text { Bergamot, lemon, } \\
\text { tea tree }\end{array}$ & $0-2 / 1$ & WVP was reduced & - & [64] \\
\hline Chitosan & Bergamot & $0-3 / 1$ & WVP was reduced & - & {$[50]$} \\
\hline Chitosan & Tea tree & $0-2 / 1$ & WVP was reduced & - & [51] \\
\hline HPMC & Tea tree & $0-2 / 5$ & WVP was reduced & - & [93] \\
\hline Chitosan & Basil, thyme & $0-0.5 / 1$ & WVP was reduced & - & [57] \\
\hline Chitosan & Cinnamon leaf & $0-0.5 / 1$ & WVP was increased & OP was increased & [58] \\
\hline $\begin{array}{l}\text { Starch-gelatin } \\
\text { blend }\end{array}$ & $\begin{array}{l}\text { Oregano, clove, } \\
\text { cinnamon bark }\end{array}$ & $0-0.25 / 1$ & WVP was reduced & OP was reduced & [59] \\
\hline Chitosan & $\begin{array}{l}\text { Eugenol, cinnamon } \\
\text { leaf }\end{array}$ & $0.476 / 1$ & WVP reduced by eugenol & - & [60] \\
\hline
\end{tabular}

Table 5: Tensile properties (elastic modulus: EM, tensile strength: TS and percentage elongation at breack: \%E) of biopolymer films as affected by the presence of EO.

\begin{tabular}{|c|c|c|c|c|c|c|}
\hline \multirow[t]{2}{*}{ Matrix } & \multirow[t]{2}{*}{ EO } & \multirow{2}{*}{$\begin{array}{l}\text { Concentration } \\
\text { (g/g polymer) }\end{array}$} & \multicolumn{3}{|c|}{ Main observations on the effect of EO incorporation } & \multirow[t]{2}{*}{ Reference } \\
\hline & & & EM & TS & $\% \mathrm{E}$ & \\
\hline Soy protein & $\begin{array}{l}\text { Carvacrol, } \\
\text { cinnamaldehyde }\end{array}$ & $0.67 / 10$ & Increased & Increased & Increased & {$[88$} \\
\hline $\begin{array}{l}\text { Lignocellulos } \\
\text { e }\end{array}$ & Cedarwood & $0-0.2 / 1$ & Reduced & Reduced & $\begin{array}{l}\text { Slightly } \\
\text { increased }\end{array}$ & [89] \\
\hline $\begin{array}{l}\text { Fish gelatin } \\
\text { and chitosan }\end{array}$ & $\begin{array}{l}\text { Origanum } \\
\text { vulgare }\end{array}$ & $0.4-1.2 \% / 1.75 \%$ & Reduced & Reduced & No effect & [90] \\
\hline Gelatin & $\begin{array}{l}\text { Oregano, } \\
\text { lavender }\end{array}$ & $0.04-0.12 / 1$ & Non reported & Reduced & No effect & [91] \\
\hline Alginate & $\begin{array}{l}\text { Thyme, } \\
\text { lemongrass, } \\
\text { sage }\end{array}$ & $1 / 3$ & Non reported & No effect & $\begin{array}{l}\text { No effect/ } \\
\text { increased }\end{array}$ & [38] \\
\hline Whey protein & Almond, walnut & $1 / 8$ & No effect & No effect & $\begin{array}{l}\text { No effect/ } \\
\text { increased }\end{array}$ & [92] \\
\hline Mucilage & Oregano & $0-2 / 35$ & Reduced & Reduced & Increased & [42] \\
\hline \multirow{2}{*}{$\begin{array}{l}\text { Soy protein } \\
\text { isolate }\end{array}$} & Cinnamon & $0.1 / 1$ & No effect & Increased & Increased & [98] \\
\hline & Ginger & $0.1 / 1$ & Reduced & Reduced & No effect & [98] \\
\hline Chitosan & Cinnamon & $0.1 / 1$ & - & Increased & Reduced & [26] \\
\hline Alginate & Oregano & $0-1 / 1$ & - & Reduced & Increased & [37] \\
\hline HPMC, & Bergamot, & $0-2 / 1$ & Reduced & Reduced & Reduced & [64] \\
\hline
\end{tabular}




\begin{tabular}{lllllll}
\hline chitosan & lemon, tea tree & & & & & \\
\hline Chitosan & Bergamot & $0-3 / 1$ & Reduced & Reduced & Reduced & {$[50]$} \\
\hline Chitosan & Tea tree & $0-2 / 1$ & Reduced & Reduced & Reduced & {$[51]$} \\
\hline HPMC & Tea tree & $0-2 / 5$ & Reduced & Reduced & No effect & {$[93]$} \\
\hline Chitosan & Basil, thyme & $0-0.5 / 1$ & Increased & Increased & Reduced & {$[57]$} \\
\hline Chitosan & Cinnamon leaf & $0-0.5 / 1$ & Reduced & Reduced & Increased & {$[58]$} \\
\hline $\begin{array}{l}\text { Starch- } \\
\text { gelatin blend } \\
\text { Chitosan }\end{array}$ & $\begin{array}{l}\text { Oregano, clove, } \\
\text { cinnamon bark }\end{array}$ & $0-0.25 / 1$ & No effect & No effect & No effect & {$[59]$} \\
& $\begin{array}{l}\text { Eugenol, } \\
\text { cinnamon leaf }\end{array}$ & $0.476 / 1$ & Reduced & Reduced & No effect & {$[60]$} \\
\hline
\end{tabular}

have been determined by applying first order kinetics equations [82, 106]. Likewise, the diffusion coefficients (D) of compounds have been quantified by fitting Fick's model to the concentration of the active in the food simulant vs. time [75, 81, 82, 107]. The fitting of the Peppas model allows us to obtain information about the coupling of the different mechanisms involved in the process, through the value of the potential coefficient $n$. Values of $n$ in the range of 0.5 indicate a prevailing Fickian mechanism.

In the case of essential oil compounds embedded in polymer films, there are different factors that influence the compound migration from films to the food system: (i) the physicochemical properties of the migrant substance, such as volatility, polarity and solubility; (ii) the polymer hydrophobicity, which determines the interactions with the EO compounds and the foodstuff; (iii) the composition and properties of the packaged food, mainly the food polarity, and (iv) the storage conditions, such as temperature [62, 100, $107,108,109]$. All of these factors implied both complex interactions, which make controlled release predictions difficult, and also the necessity for specific studies of a determined packaging material and food system. The use of standardized food simulants can help to compare the migration of different materials, but differences in composition with respect to real foods could lead to divergent results, since particular interactions with different food components may affect migration behaviour and food quality and safety.

As previously commented on, many biopolymers with film forming properties, such as chitosan, starch, modified cellulose, alginate, whey protein or gelatin, are water soluble whereas the EO compounds are non-polar substances [78]. To promote compatibility, what has been analysed is the encapsulation of EO by means of different strategies, affecting the compound release kinetics. Table 6 and 7 summarizes previous studies into the release of actives, encapsulated or not, into different food matrices or simulants. Wu et al. [110] reported a reduction in the release rate of cinnamon EO from fish gelatin films into corn oil as a result of their inclusion in nanoliposomes, which prolongs the activity thus improving the antimicrobial action. In the same way, the encapsulation of carvacrol in $\beta$-cyclodextrins reduced the carvacrol release rate from whey protein isolated
(WPI) films [77] and cellulose nanocrystal films [111]. However, the release rate of eugenol was not significantly affected by its inclusion in $\beta$-cyclodextrin in WPI films, which was attributed to the weak interactions between the compound and cyclodextrins [77]. Nanofillers, such as halloysite nanotubes, were also effective at controlling the release of peppermint EO from pectin films, increasing the EO adsorption capacity of the polymer matrix [106]. Likewise, sepiolite nanofillers slowed down and prolonged the eugenol release from clove EO-gelatin films, through the control of the EO interactions with the polymer matrix [113]. Matiacevich et al. [78] highlighted the effect of the structure of the polymer matrix on the release parameters of lemongrass EO, encapsulated in sodium caseinate microcapsules, when included in alginate films. The more ordered structure of the film greatly slowed down the release rate.

The concentration of the active compound in the film also affects release kinetics. Chen et al. [112] reported an increase in the release rate of nanoemulsified cinnamaldehyde when its concentration rose up to a carbonyl:amino molar ratio of 1 in chitosan films. However, higher contents led to slower delivery rates, which was attributed to microstructural changes that restricted molecular diffusion through the polymer matrix.

The chemical compatibility between the active compound and the foodstuff is a decisive factor in the release of the active agent. Thus, active devices based on chitosan containing $\beta$-cyclodextrin-carvacrol complexes, placed in tight packages containing chicken samples, produced carvacrol deliveries of between 95-99\% after 9 days of storage, whereas packages without chicken samples only released 35\% of the active agent [62]. The great chemical affinity between the carvacrol and the chicken protein promoted carvacrol adsorption in the food, which, while limiting antimicrobial action, affected the sensory properties. Similar effects were observed for Zataria multiflora Boiss EO (ZEO) embedded in chitosan films when applied on mortadella sausages, where a fast and total release of ZEO compounds was observed due to their great affinity with the mortadella fat. Nevertheless, this was mitigated when applied in combination with grape seed extract with higher molecular weight compounds, which interact with ZEO constituents [109]. These observations have also been proven 
Table 6. Release kinetics studies for different encapsulated essential oil (EO) compounds from polymer matrices.

\begin{tabular}{|c|c|c|c|c|c|}
\hline $\begin{array}{l}\text { Active } \\
\text { compound }\end{array}$ & $\begin{array}{l}\text { Encapsulating } \\
\text { agent }\end{array}$ & Polymer & $\begin{array}{l}\text { Simulant } \\
\text { or food }\end{array}$ & Main features & Reference \\
\hline $\begin{array}{l}\text { Menthone from } \\
\text { peppermint EO }\end{array}$ & $\begin{array}{l}\text { Halloysite } \\
\text { nanotubes }\end{array}$ & Pectine & $\begin{array}{l}\text { Ethanol } \\
50 \% \mathrm{v} / \mathrm{v}\end{array}$ & $\begin{array}{l}\text { Encapsulation contributed to the adsorption } \\
\text { of actives in the film, thus increasing its } \\
\text { release capacity. Films only deliver } 4-20 \% \\
\text { of the active depending on temperature. } \\
\text { Fitted model: first order kinetics. }\end{array}$ & [106] \\
\hline Lemongrass EO & $\begin{array}{l}\text { Caseinate } \\
\text { microcapsules }\end{array}$ & $\begin{array}{l}\text { Sodium } \\
\text { alginate }\end{array}$ & $\begin{array}{l}\text { Ethanol } \\
50 \% \mathrm{v} / \mathrm{v}\end{array}$ & $\begin{array}{l}\text { Encapsulated compounds in the film showed } \\
\text { a more sustained Fickian release than in the } \\
\text { free capsules. } \\
\text { Fitted models: Peppas and Weibull } \\
\text { equations. }\end{array}$ & [78] \\
\hline Cinnamon EO & Nanoliposomes & $\begin{array}{l}\text { Fish } \\
\text { gelatin }\end{array}$ & Corn oil & $\begin{array}{l}\text { The cinnamon EO inclusion in } \\
\text { nanoliposomes allowed for a more } \\
\text { controlled release of the actives. } \\
\text { No fitted model. }\end{array}$ & [110] \\
\hline Carvacrol & $\beta$-cyclodextrins & $\begin{array}{l}\text { Cellulose } \\
\text { nanocrys } \\
\text { tals }\end{array}$ & Water & $\begin{array}{l}\text { Encapsulation in } \beta \text {-cyclodextrins allowed for } \\
\text { better absorption of the actives in the films } \\
\text { while retarding their release. } \\
\text { No fitted model. }\end{array}$ & [111] \\
\hline $\begin{array}{l}\text { Carvacrol or } \\
\text { eugenol }\end{array}$ & $\beta$-cyclodextrins & $\begin{array}{l}\text { Whey } \\
\text { protein }\end{array}$ & $\begin{array}{l}\text { Ethanol } \\
50 \% \mathrm{v} / \mathrm{v}\end{array}$ & $\begin{array}{l}\beta \text {-cyclodextrin inclusion complexes slowed } \\
\text { down the carvacrol release rate, but they did } \\
\text { not affect the eugenol release rate. } \\
\text { Fitted model: first order kinetics }\end{array}$ & [77] \\
\hline Carvacrol & $\beta$-cyclodextrins & Chitosan & $\begin{array}{l}\text { Chicken } \\
\text { fillets }\end{array}$ & $\begin{array}{l}\text { Carvacrol release from chitosan- } \\
\text { ciclodextrins films in the package head } \\
\text { space was greatly promoted when there was } \\
\text { a sample of chicken, due to its adsorption in } \\
\text { the sample protein (95-99\% compared to } \\
35 \% \text { without chicken) } \\
\text { No fitted model. }\end{array}$ & [62] \\
\hline Cinnamaldehyde & $\begin{array}{l}\text { Triglyceride- } \\
\text { twin 80- } \\
\text { nanoemulsions }\end{array}$ & $\begin{array}{l}\text { Chitosan } \\
(278 \\
\text { kDa) }\end{array}$ & $\begin{array}{l}\text { Ethanol } \\
10 \% \mathrm{v} / \mathrm{v} \\
\text { and } \\
\text { ethanol } \\
50 \% \mathrm{v} / \mathrm{v}\end{array}$ & $\begin{array}{l}\text { The release rate of nanoemulsified } \\
\text { cinnamaldehyde rose when its concentration } \\
\text { increased up to a carbonyl:amino molar ratio } \\
\text { of } 1 \text { in chitosan films, but higher contents } \\
\text { led to slower delivery rates. Ethanol } \\
\text { promoted release rate. } \\
\text { No fitted model. }\end{array}$ & [112] \\
\hline
\end{tabular}

Table 7. Release kinetics studies for different essential oil (EO) compounds from polymer matrices.

\begin{tabular}{|c|c|c|c|c|}
\hline Active compound & Polymer & Simulant or food & Main features & Reference \\
\hline Carvacrol & $\begin{array}{l}\text { Chitosan (400, } \\
180 \text { and } 41 \mathrm{kDa})\end{array}$ & $\begin{array}{l}\text { Olive oil and } \\
\text { ethanol } 96 \% \mathrm{v} / \mathrm{v}\end{array}$ & $\begin{array}{l}\text { Release rate increased when the chitosan } \\
\text { molecular weight rose. In ethanol, carvacrol } \\
\text { delivery was faster and more complete than in } \\
\text { olive oil. } \\
\text { No fitted model. }\end{array}$ & {$[100]$} \\
\hline $\begin{array}{l}\text { Zataria multiflora } \\
\text { Boiss EO } \\
\text { (combined or not } \\
\text { with grape seed } \\
\text { extract-GSE) }\end{array}$ & $\begin{array}{l}\text { Chitosan (450 } \\
\mathrm{kDa})\end{array}$ & $\begin{array}{l}\text { Mortadella } \\
\text { sausage }\end{array}$ & $\begin{array}{l}\text { Migration of EO compounds to the product was } \\
\text { slowed down when combined with GSE. } \\
\text { Complete delivery occurred in } 6 \text { days for EO } \\
\text { without GSE. } \\
\text { No fitted model. }\end{array}$ & [109] \\
\hline $\begin{array}{l}\text { Limonene from } \\
\text { Bergamota EO }\end{array}$ & $\begin{array}{l}\text { Chitosan } \\
\text { (medium } \\
\text { molecular } \\
\text { weight) }\end{array}$ & $\begin{array}{l}\text { Water, ethanol } \\
10 \% \mathrm{v} / \mathrm{v} \text {, ethanol } \\
50 \% \mathrm{v} / \mathrm{v} \text {, ethanol } \\
95 \% \mathrm{v} / \mathrm{v} \text { and } \\
\text { isooctane }\end{array}$ & $\begin{array}{l}\text { The release kinetics of limonene was promoted } \\
\text { when ethanol ratio rose (greater limonene } \\
\text { solubility), but the non-polar system implied a } \\
\text { very slow delivery rate since it did not provoke } \\
\text { swelling of the polymer matrix. } \\
\text { Fitted model: Fickian equation. }\end{array}$ & [107] \\
\hline Cinnamaldehyde & Agar and sodium & Water & Maximum release (35\% of the total content) of & [76] \\
\hline
\end{tabular}




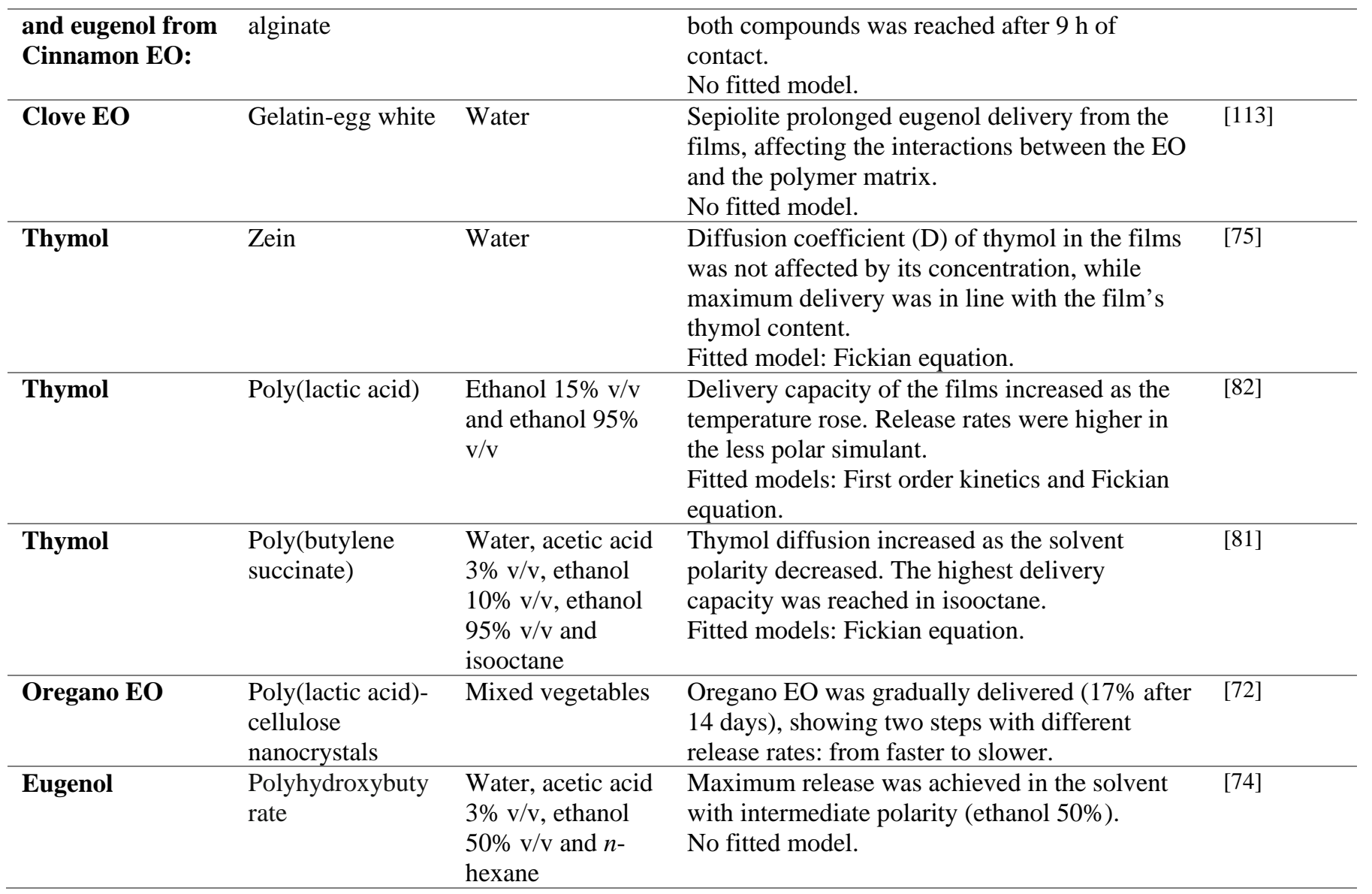

in food simulants; Petchwattana and Naknaen [81] and Tawakkal et al. [82] analysed the release kinetics of thymol from poly(butylene succinate) and poly(lactic acid) films, respectively, and reported that the maximum release rates were observed with hydrophobic food simulants, such as 95\% ethanol and isooctane, due to the greater chemical affinity between thymol and the non-polar solvents. Likewise, Sánchez-González et al. [107] observed a higher release at the equilibrium of limonene from chitosan films as the ethanol percentage increased in the food simulant, in line with the low polarity of limonene. However, no notable delivery of active compounds occurred in isooctane due to the lack of swelling of the polymer matrix, which tightly entraps the active.

Temperature greatly affects the kinetics of active compound delivery from a determined film in a specific medium. Temperature affects the molecular interactions in both film matrices and food systems, and therefore the chemical affinity between the active compounds and the respective substrate can change, provoking different migration behaviour. In general, low temperatures slow down migration kinetics, according to its effect on molecular diffusion, but the equilibrium status can also be modified due to the differences in the involved molecular interactions. In this sense, different authors [106, 110] report a significant effect of temperature on the delivery kinetics of the EO active compounds.

\section{FOOD APPLICATIONS OF ACTIVE BIOPOLYMER FILMS CONTAINING EO/COMPOUNDS.}

During the last decade, many studies have been carried out on the use of biopolymers as carriers of EOs and their main compounds, with the aim of responding to consumer demand for preservative-free, safer products. Thus, different carbohydrate polymers, such as chitosan, cellulose derivatives, alginates, gelatin, etc., have been used both to incorporate EO and develop film formulations for the purposes of improving the food quality and extending its shelf life. Different plant and animal proteins, such as gelatin, whey, soy and milk proteins, have also been extensively used. Table 8 summarizes several recent studies using these kinds of biopolymers. The use of other biopolymers, such as aliphatic polyesters [127], as carriers of antimicrobials is also being investigated in order to obtain active materials for food packaging (Table 9). Among the most outstanding is polylactic acid (PLA), polycaprolactone (PCL) or the polyhydroxyalkanoates, such as polyhydroxybutyrate (PHB) and polyhydroxybutyrate-cohydroxivalerate (PHBV) [129]. Among the most effective compounds/EOs may be found carvacrol, thymol, cinnamaldehyde or oregano, cinnamon and clove EOs, attaining the total microbial inhibition of several foodborne pathogens. Some studies are summarized in Tables 8 and 9 and commented on below. 
Table 8. Recent studies on applications of active films from food hydrocolloids and EO compounds into food systems.

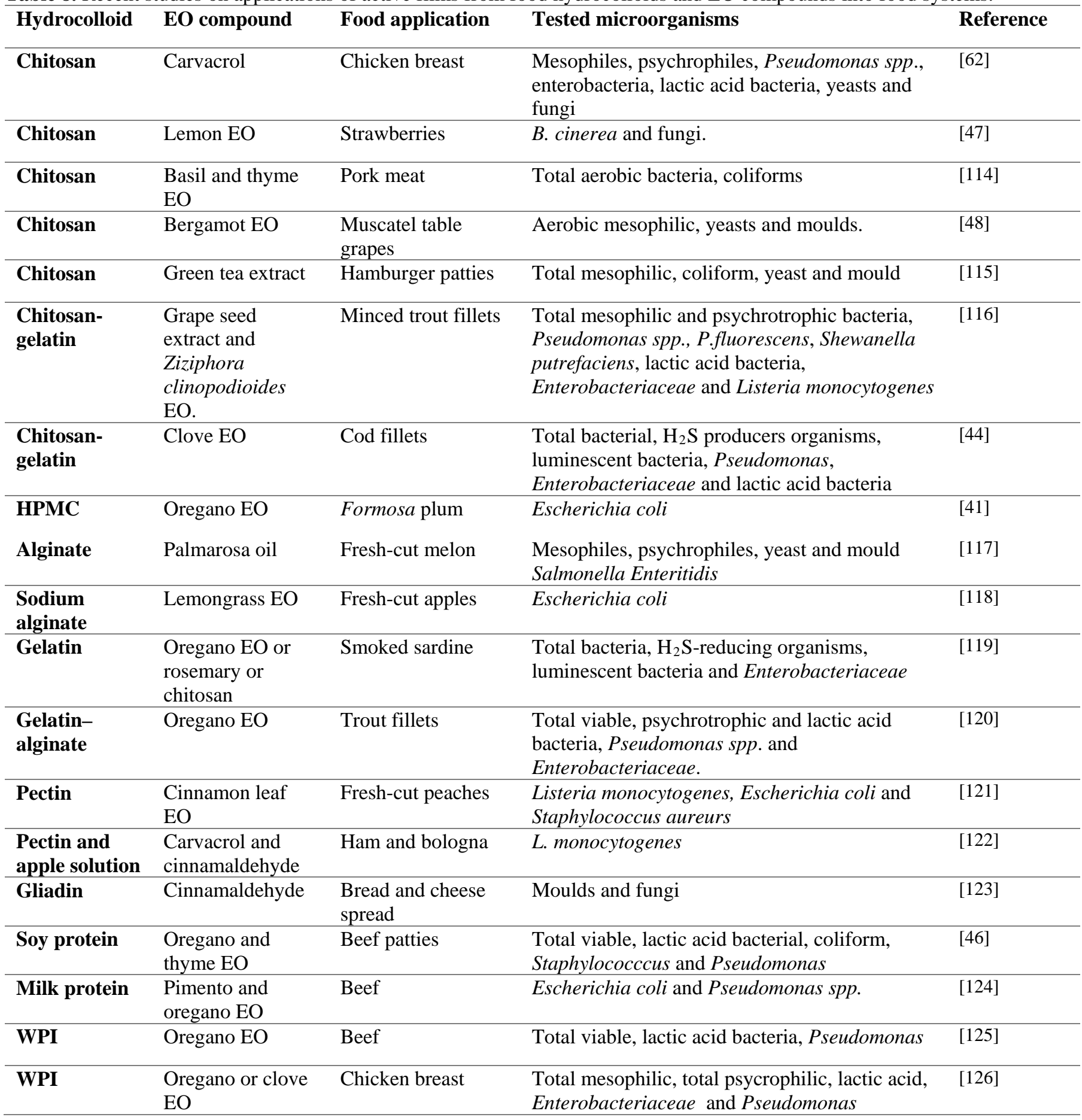

Table 9. Recent studies on applications of biodegradable polymer active films with EO compounds into food systems.

\begin{tabular}{llll}
\hline $\begin{array}{l}\text { Biodegradable } \\
\text { polymer }\end{array}$ & EO compound & $\begin{array}{l}\text { Food } \\
\text { application }\end{array}$ & Microorganism tested \\
\hline Polylactic acid & Cinnamon EO & Chicken & $\begin{array}{l}\text { Listeria monocytogenes and Salmonella } \\
\text { typhimurium (in vitro and in vivo) }\end{array}$ \\
\hline Polylactic acid & Oregano EO & Rainbow trout & $\begin{array}{l}\text { S. aureus, L. monocytogenes, E. coli and S. } \\
\text { Enteritidis (in vitro) } \\
\text { [70tal viable count, psychrotrophilic count, } \\
\text { lactic acid bacteria and Enterobacteruaceae } \\
\text { count (in vivo) }\end{array}$ \\
\hline
\end{tabular}




\begin{tabular}{|c|c|c|c|c|}
\hline Polylactic acid & $\begin{array}{l}\text { Cinnamon EO/ } \beta \text { - } \\
\text { cyclodextrins }\end{array}$ & Pork meat & $\begin{array}{l}\text { E. coli and S. aureus (in vitro) } \\
\text { Viable microbial counts (in vivo) }\end{array}$ & [86] \\
\hline $\begin{array}{l}\text { Polylactic acid } \\
\text { and } \\
\text { polycaprolactone }\end{array}$ & Cinnamaldehyde & $\begin{array}{l}\text { Button } \\
\text { mushroom }\end{array}$ & Mesophilic and psychrophilic counts & [53] \\
\hline $\begin{array}{l}\text { Poly(lactic acid) } \\
\text { and cellulose } \\
\text { nanocrystals }\end{array}$ & Oregano EO & $\begin{array}{l}\text { Mixed } \\
\text { vegetables }\end{array}$ & $\begin{array}{l}5 \text { strains of L. monocytogenes HPB (2569, } \\
2558,2371,2812 \text { and 1043) }\end{array}$ & [72] \\
\hline $\begin{array}{l}\text { Polycaprolactone } \\
\text { and } \\
\text { metylcellulose }\end{array}$ & $\begin{array}{l}\text { Two blends: (i) organic } \\
\text { acids, extract of } \\
\text { rosmarinic acid and } \\
\text { Asian EO mixture; (ii) } \\
\text { organic acids, extract of } \\
\text { rosmarinic acid and } \\
\text { Italian EO mixture. }\end{array}$ & Fresh broccoli & $\begin{array}{l}\text { L. monocytogenes, S. typhimurium, E. coli } \\
\text { and total aerobic microbiota (TAM). }\end{array}$ & [128] \\
\hline
\end{tabular}

PLA films with cinnamon EO significantly reduced the bacterial growth in chicken samples inoculated with L. monocytogenes or S. typhimurium [70]. Likewise, PLAcinnamon EO films doubled the pork's shelf life by maintaining the microbial counts below $1.107 \mathrm{CFU} / \mathrm{ml}$ or $\mathrm{g}$ or $\mathrm{cm} 2$ for 8 days. [86]. Similarly, PLA films with oregano EO have been used to package rainbow trout, thus reducing the total viable counts by half after 12 days of cold storage, keeping these values below the recommended limit. At the same time, the microbial growth of psychrotrophic bacteria, lactic acid bacteria and Enterobacteriaceae was delayed as a result of the oregano EO's antimicrobial activity.

Often, films based on biopolymer blends are used as carriers of these active compounds, since they usually demonstrate better physical properties. In this sense, cinnamaldehyde has been included in PLA-PCL films, which reduced the microbial growth on button mushrooms [53]. Likewise, PCL-methylcellulose films with extract of rosmarinic and Asian or Italian EO mixture inhibit the microbial growth of E. coli and Salmonella Typhimurium in broccoli, while showed a bacteriostatic effect at 12 and 7 days, respectively [128]. In vitro tests with PHB films containing eugenol exhibited antimicrobial activity, with a minimum inhibitory concentration (MIC) of eugenol in the films of 40 and $80 \mu \mathrm{g}$ eugenol/g PHB for bacteria and fungi, respectively. A total microbial inhibition was observed with a eugenol content of over $200 \mu \mathrm{g} / \mathrm{g}$ PHB [74]. In the same way, Requena et al., [67] reported that PHBV films with carvacrol, eugenol or oregano EO had a fast bactericide effect against E.coli, whereas less, more gradual antimicrobial activity was observed against $L$. innocua.

Despite the remarkable antimicrobial activity of the EO against most foodborne pathogens in in vitro tests, several authors have reported that higher amounts are required to achieve similar results on real foodstuffs. This fact can be explained by the interactions of some food ingredients with the EO compounds, which sequester them, thereby limiting their antimicrobial activity. In general, high contents of proteins or fats have been related with a lower bacterial sensitivity to the EO [130-133], whereas this has not been observed with high carbohydrate contents [131]. In addition, the higher nutrient availability on the food, compared to the culture media, would allow for faster damage repair by bacteria [134]. Thus, despite the proven antimicrobial properties of several EOs in culture media, very low or null antibacterial activity was observed for these EOs against $E$. coli in ready-to-cook chicken [135]; S. typhimurium in beef [136]; Y. enterocolitica and L. monocytogenes in chicken [137]; and L. monocytogenes in steak tartare [138]. Likewise, sachets containing carvacrol inside packaged chicken breast fillets did not give rise to an efficient microbial inhibition of fungi, yeast, mesophiles and enterobacteria, because of the headspace carvacrol was adsorbed by the chicken protein matrix, thereby keeping the active compound concentration in the packaging headspace below the MIC [62]. In the same way, edible films from apple puree containing cinnamaldehyde did not exhibit antimicrobial activity against L. monocytogenes in ham, at different active compound concentrations and storage temperatures [122]. Nor did PCL-methylcellulose films containing extract of rosmarinic acid and Italian or Asian EO mixture have any effect on the L. monocytogenes growth in fresh broccoli [128]. Therefore, although the antimicrobial activity of many EOs has been proven in in vitro studies and with some specific foodstuffs, the development of active packaging requires specific studies with a determined food product to ensure antimicrobial effectiveness and food safety.

\section{CONCLUSION}

From the point of view of their potential properties, proven in in vitro studies, the perspective of using essential oils as antimicrobial or antioxidant components of biopolymer active packaging materials is good. However, their incorporation into polymer matrices leads to changes in the films' functional properties as packaging material and their release is conditioned by the marked interactions with both some food components, as well as with the film matrix. Therefore, a biopolymer film-food system-active compound represents a complex environment, which makes predicting the bioactivity of a compound difficult. Thus, specific studies into a real food need be performed to ensure both the effectiveness of the active against a target microorganism and also the total adsorption of actives in the food matrix, with the corresponding impact on its sensory and quality characteristics. 


\section{ACKNOWLEDGEMENTS}

The authors acknowledge the financial support provided by Ministerio de Economía y Competividad (Project AGL2013-42989-R).

\section{REFERENCES}

[1] Yu, L.; Dean, K.; Bi, L. Polymer blends and composites from renewable resources. Progress in Polymer Science, 2006, 31, 576602.

[2] Zhang, J. F.; Sun, X. Mechanical and thermal properties of poly(lacticacid)/starch blends with dioctyl maleate. Journal of Applied Polymer Science, 2004, 94, 1697-1704.

[3] Raquez, J. M.; Degée, P.; Nabar, Y.; Narayan, R.; Dubois, P. Biodegradable materials by reactive extrusion: from catalyzed polymerization to functionalization and blend compatibilization. Comptes Rendus Chimie, 2006, 9(11), 13701379.

[4] Ortega-Toro, R.; Morey, I.; Talens, P.; Chiralt, A. Active bilayer films of thermoplastic starch and polycaprolactone obtained by compression molding. Carbohydrate polymers, 2015, 127, 282290.

[5] Alves-Silva, J.M.; Dias dos Santos, S.M.; Pintado, M.E.; PérezÁlvarez J.A.; Fernández-López, J.; Viuda-Martos, M. Chemical composition and in vitro antimicrobial, antifungal and antioxidant properties of essential oils obtained from some herbs widely used in Portugal. Food Control, 2013, 32 (2), 371-378.

[6] Ruiz-Navajas, Y.; Viuda-Martos, M.; Sendra, E.; Perez-Alvarez, J. A.; Fernández-López, J. In vitro antibacterial and antioxidant properties of chitosan edible films incorporated with Thymus moroderi or Thymus piperella essential oils. Food Control, 2013, 30(2), 386-392.

[7] Lambert, R. J. W.; Skandamis, P. N.; Coote, P. J.; Nychas, G. J. A study of the minimum inhibitory concentration and mode of action of oregano essential oil, thymol and carvacrol. Journal of Applied Microbiology, 2001, 91(3), 453-462.

[8] Neto, N. J. G.; Magnani, M.; Chueca, B.; García-Gonzalo; D., Pagán, R.; de Souza, E. L. Influence of general stress-response alternative sigma factors $\sigma \mathrm{S}(\mathrm{RpoS})$ and $\sigma \mathrm{B}(\mathrm{SigB})$ on bacterial tolerance to the essential oils from Origanum vulgare L. and Rosmarinus officinalis L. and pulsed electric fields. International Journal of Food Microbiology, 2015, 211, 32-37.

[9] Cox, S. D.; Mann, C. M.; Markham, J. L.; Gustafson, J. E.; Warmington, J. R.; Wyllie, S. G. Determining the antimicrobial actions of tea tree oil. Molecules, 2001, 6(2), 87-91.

[10] Picone, G.; Laghi, L.; Gardini, F.; Lanciotti, R.; Siroli, L.Capozzi, F. Evaluation of the effect of carvacrol on the Escherichia coli 555 metabolome by using 1 HNMR spectroscopy. Food Chemistry, 2013, 41, 4367-4374.

[11] Ultee, A.; Kets, E. P.; Alberda, M.; Hoekstra, F. A.; Smid, E. J. Adaptation of the food-borne pathogen Bacillus cereus to carvacrol. Archives of Microbiology, 2000, 174(4), 233-238.

[12] Ultee, A.; Smid, E. J. Influence of carvacrol on growth and toxin production by Bacillus cereus. International journal of food microbiology, 2001, 64(3), 373-378.

[13] Gustafson, J. E.; Liew, Y. C.; Chew, S.; Markham, J.; Bell, H. C.; Wyllie, S. G.; Warmington, J. R. Effects of tea tree oil on Escherichia coli. Letters in applied microbiology, 1998, 26(3), 194198.

[14] Alves de Azerêdo, G.; Stamford, T. L. M.; Queiroz de Figueiredo, R. C. B.; Leite de Souza, E. The cytotoxic effect of essential oils from Origanum vulgare $L$. and/or Rosmarinus officinalis $L$. on Aeromonas hydrophila. Foodborne Pathogens and Disease, 2012, 9(4), 298-304.

[15] de Jesus, I. C.; Frazão, G. G. S.; Blank, A. F.; de Aquino Santana, L. C. L. Myrcia ovata Cambessedes essential oils: A proposal for a novel natural antimicrobial against foodborne bacteria. Microbial Pathogenesis, 2016, 99, 142-147.

[16] Ud-Daula, A. S.; Demirci, F.; Salim, K. A.; Demirci, B.; Lim, L. B.; Baser, K. H. C.; Ahmad, N. Chemical composition, antioxidant and antimicrobial activities of essential oils from leaves, aerial stems, basal stems, and rhizomes of Etlingera fimbriobracteata (K. Schum.) R.M.Sm. Industrial Crops and Products, 2016, 84, 189198.
Verma, S. K.; Goswami, P.; Verma, R. S.; Padalia, R. C.; Chauhan, A.; Singh, V. R.; Darokar, M. P. Chemical composition and antimicrobial activity of bergamot-mint (Mentha citrata Ehrh.) essential oils isolated from the herbage and aqueous distillate using different methods. Industrial Crops and Products, 2016, 91, 152160.

[18] Ma, Q.; Davidson, P. M.; Zhong, Q. Antimicrobial properties of microemulsions formulated with essential oils, soybean oil, and Tween 80. International journal of food microbiology, 2016, 226, 20-25.

[19] Said, Z. B. O. S.; Haddadi-Guemghar, H.; Boulekbache-Makhlouf, L.; Rigou, P.; Remini, H.; Adjaoud, A.; ...; Madani, K. Essential oils composition, antibacterial and antioxidant activities of hydrodistillated extract of Eucalyptus globulus fruits. Industrial Crops and Products, 2016, 89, 167-175.

[20] Boubaker, H.; Karim, H.; El Hamdaoui, A.; Msanda, F.; Leach, D. Bombarda, I.; ... ; Aoumar, A. A. B. Chemical characterization and antifungal activities of four Thymus species essential oils against postharvest fungal pathogens of citrus. Industrial Crops and Products, 2016, 86, 95-101.

[21] Clemente, I.; Aznar, M.; Silva, F.; Nerín, C. Antimicrobial properties and mode of action of mustard and cinnamon essential oils and their combination against foodborne bacteria. Innovative Food Science \& Emerging Technologies, 2016, 36, 26-33.

[22] Sarikurkcu, C.; Zengin, G.; Oskay, M.; Uysal, S.; Ceylan, R. Aktumsek, A. Composition, antioxidant, antimicrobial and enzyme inhibition activities of two Origanum vulgare subspecies (subsp. vulgare and subsp. hirtum) essential oils. Industrial Crops and Products, 2015, 70, 178-184.

[23] Nikolić, M.; Jovanović, K. K.; Marković, T.; Marković, D.; Gligorijević, N.; Radulović, S.; Soković, M. Chemical composition, antimicrobial, and cytotoxic properties of five Lamiaceae essential oils. Industrial Crops and Products, 2014, 61, 225-232.

[24] Adrar, N.; Oukil, N.; Bedjou, F. Antioxidant and antibacterial activities of Thymus numidicus and Salvia officinalis essential oils alone or in combination. Industrial Crops and Products, 2016, 88, 112-119.

[25] Sánchez-Aldana, D. S.; Andrade-Ochoa, S.; Aguilar, C. N.; Contreras-Esquivel, J. C.; Nevárez-Moorillón, G. V. Antibacterial activity of pectic-based edible films incorporated with Mexican lime essential oil. Food Control, 2015, 50, 907-912.

[26] Ojagh, S. M.; Rezaei, M.; Razavi, S. H.; Hosseini, S. M. H. Development and evaluation of a novel biodegradable film made from chitosan and cinnamon essential oil with low affinity toward water. Food Chemistry, 2010, 122(1), 161-166.

[27] Miladi, H.; Mili, D.; Slama, R. B.; Zouari, S.; Ammar, E.; Bakhrouf, A. Antibiofilm formation and anti-adhesive property of three mediterranean essential oils against a foodborne pathogen Salmonella strain. Microbial Pathogenesis, 2016a, 93, 22-31.

[28] Ouedrhiri, W.; Balouiri, M.; Bouhdid, S.; Moja, S.; Chahdi, F. O.; Taleb, M.; Greche, H. Mixture design of Origanum compactum, Origanum majorana and Thymus serpyllum essential oils: Optimization of their antibacterial effect. Industrial Crops and Products, 2016, 89, 1-9.

[29] Radaelli, M.; Silva, B. P. D.; Weidlich, L.; Hoehne, L.; Flach, A.; Costa, L. A. M. A. D.; Ethur, E. M. Antimicrobial activities of six essential oils commonly used as condiments in Brazil against Clostridium perfringens. Brazilian Journal of Microbiology, 2016, 47(2), 424-430.

[30] Kim, S. A.; Rhee, M. S. Highly enhanced bactericidal effects of medium chain fatty acids (caprylic, capric, and lauric acid) combined with edible plant essential oils (carvacrol, eugenol, $\beta$ resorcylic acid, trans-cinnamaldehyde, thymol, and vanillin) against Escherichia coli O157: H7. Food Control, 2016, 60, 447454.

[31] Khare, A. K.; Biswas, A. K.; Sahoo, J. Comparison study of chitosan, EDTA, eugenol and peppermint oil for antioxidant and antimicrobial potentials in chicken noodles and their effect on colour and oxidative stability at ambient temperature storage. LWTFood Science and Technology, 2014, 55(1), 286-293.

[32] Dhara, L.; Tripathi, A. Antimicrobial activity of eugenol and cinnamaldehyde against extended spectrum beta lactamase producing enterobacteriaceae by in vitro and molecular docking analysis. European Journal of Integrative Medicine, 2013, 5(6), 527-536. 
[33] Ye, H.; Shen, S.; Xu, J.; Lin, S.; Yuan, Y.; Jones, G. S. Synergistic interactions of cinnamaldehyde in combination with carvacrol against food-borne bacteria. Food Control, 2013, 34(2), 619-623.

[34] Miladi, H.; Zmantar, T., Chaabouni, Y.; Fedhila, K.; Bakhrouf, A.; Mahdouani, K.; Chaieb, K. Antibacterial and efflux pump inhibitors of thymol and carvacrol against food-borne pathogens. Microbial Pathogenesis, 2016b, 99, 95-100.

[35] de Souza, E. L. The effects of sublethal doses of essential oils and their constituents on antimicrobial susceptibility and antibiotic resistance among food-related bacteria: A review. Trends in Food Science \& Technology, 2016, 56, 1-12.

[36] Gutierrez, J.; Barry-Ryan, C.; Bourke, P. Antimicrobial activity of plant essential oils using food model media: efficacy, synergistic potential and interactions with food components. Food microbiology, 2009, 26(2), 142-150.

[37] Benavides, S.; Villalobos-Carvajal, R.; Reyes, J. E. Physical, mechanical and antibacterial properties of alginate film: effect of the crosslinking degree and oregano essential oil concentration. Journal of Food Engineering, 2012, 110(2), 232239.

[38] Acevedo-Fani, A.; Salvia-Trujillo, L.; Rojas-Graü, M. A.; MartínBelloso, O. Edible films from essential-oil-loaded nanoemulsions: Physicochemical characterization and antimicrobial properties. Food Hydrocolloids, 2015, 47, 168-177.

[39] Hafsa, J.; ali Smach, M.; Khedher, M. R. B.; Charfeddine, B.; Limem, K.; Majdoub, H.; Rouatbi, S. Physical, antioxidant and antimicrobial properties of chitosan films containing Eucalyptus globulus essential oil. LWT-Food Science and Technology, 2016, 68, 356-364.

[40] Genskowsky, E.; Puente, L. A.; Pérez-Álvarez, J. A.; FernandezLopez, J.; Muñoz, L. A.; Viuda-Martos, M. Assessment of antibacterial and antioxidant properties of chitosan edible films incorporated with maqui berry (Aristotelia chilensis). LWT-Food Science and Technology, 2015, 64(2), 1057-1062.

[41] Choi, W.S.; Singh, S.; Lee, Y.S. Characterization of edible film containing essential oils in hydroxypropyl methylcellulose and its effect on quality attributes of 'Formosa' plum (Prunus salicina L.). LWT - Food Science and Technology, 2016, 70, 213-222.

[42] Jouki, M.; Yazdi, F. T.; Mortazavi, S. A.; Koocheki, A. Quince seed mucilage films incorporated with oregano essential oil: Physical, thermal, barrier, antioxidant and antibacterial properties. Food Hydrocolloids, 2014, 36, 9-19.

[43] Aliheidari, N.; Fazaeli, M., Ahmadi; R., Ghasemlou, M.; EmamDjomeh, Z. Comparative evaluation on fatty acid and Matricaria recutita essential oil incorporated into casein-based film. International Journal of Biological Macromolecules, 2013, 56, 69-75.

[44] Gómez-Estaca, J.; de Lacey, A. L.; López-Caballero, M. E.; Gómez-Guillén, M. C.; Montero, P. Biodegradable gelatinchitosan films incorporated with essential oils as antimicrobial agents for fish preservation. Food Microbiology, 2010, 27(7), 889896.

[45] Pires, C.; Ramos, C.; Teixeira, B.; Batista, I.; Nunes, M. L.; Marques, A. Hake proteins edible films incorporated with essential oils: physical, mechanical, antioxidant and antibacterial properties. Food Hydrocolloids, 2013, 30(1), 224-231.

[46] Emiroğlu, Z. K.; Yemiş, G. P.; Coşkun, B. K.; Candoğan, K. Antimicrobial activity of soy edible films incorporated with thyme and oregano essential oils on fresh ground beef patties. Meat Science, 2010, 86(2), 283-288.

[47] Perdones, A.; Sánchez-González, L.; Chiralt, A.; Vargas, M. Effect of chitosan-lemon essential oil coatings on storage-keeping quality of strawberry. Postharvest Biology and Technology, 2012, 70, 3241.

[48] Sánchez-González, L.; Pastor, C.; Vargas, M.; Chiralt, A.; González-Martínez, C.; Cháfer, M. Effect of hydroxypropylmethylcellulose and chitosan coatings with and without bergamot essential oil on quality and safety of cold-stored grapes. Postharvest Biology and Technology, 2011b, 60(1), 57-63.

[49] Sánchez-González, L.; Cháfer, M.; Hernández, M.; Chiralt, A.; González-Martínez, C. Antimicrobial activity of polysaccharide films containing essential oils. Food Control, 2011c, 22(8), 13021310 .

[50] Sánchez González, L.; Cháfer, M.; Chiralt, A.; González-Martínez, C. Physical properties of edible chitosan films containing bergamot essential oil and their inhibitory action on Penicillium italicum. Carbohydrate Polymers, 2010a, 82 (2) 277-283.
[51] Sánchez-González, L.; González-Martínez, C.; Chiralt, A.; Cháfer, M. Physical and antimicrobial properties of chitosan-tea tree essential oil composite films. Journal of Food Engineering, 2010b, 98(4), 443-452.

[52] Guerreiro, A. C.; Gago, C. M.; Miguel, M. G.; Faleiro, M. L.; Antunes, M. D. The influence of edible coatings enriched with citral and eugenol on the raspberry storage ability, nutritional and sensory quality. Food Packaging and Shelf Life, 2016, 9, 20-28.

[53] Qin, Y.; Liu, D.; Wu, Y.; Yuan, M.; Li, L.; Yang, J. Effect of PLA/PCL/cinnamaldehyde antimicrobial packaging on physicochemical and microbial quality of button mushroom (Agaricus bisporus). Postharvest Biology and Technology, 2015, 99, 73-79

[54] Sarkar, P.; Bhunia, A. K.; Yao, Y. Impact of starch-based emulsions on the antibacterial efficacies of nisin and thymol in cantaloupe juice. Food Chemistry, 2017, 217, 155-162.

[55] Makwana, S.; Choudhary, R.; Dogra, N.; Kohli, P.; Haddock, J. Nanoencapsulation and immobilization of cinnamaldehyde for developing antimicrobial food packaging material. LWT-Food Science and Technology, 2014, 57(2), 470-476.

[56] Randazzo, W.; Jiménez-Belenguer, A.; Settanni, L.; Perdones, A.; Moschetti, M.; Palazzolo, E.; ...; Moschetti, G. Antilisterial effect of citrus essential oils and their performance in edible film formulations. Food Control, 2016, 59, 750-758.

[57] Perdones, A.; Chiralt, A.; Vargas, M. Properties of film-forming dispersions and films based on chitosan containing basil or thyme essential oil. Food Hydrocolloids, 2016, 57, 271-279

[58] Perdones, A.; Vargas, M.; Atarés, L.; Chiralt, A. Physical, antioxidant and antimicrobial properties of chitosan-cinnamon leaf oil films as affected by oleic acid. Food Hydrocolloids, 2014, 36, 256-64.

[59] Acosta, S.; Chiralt, A.; Santamarina, P.; Rosello, J.; GonzálezMartínez, C.; Cháfer, M. Antifungal films based on starch-gelatin blend, containing essential oils. Food Hydrocolloids, 2016, 61, 233-240.

[60] Valencia-Sullca, C.; Jiménez, M.; Jiménez, A.; Atarés, L., Vargas, M.; Chiralt, A. Influence of liposome encapsulated essential oils on properties of chitosan films. Polymer International, 2016, 65, 979987.

[61] Roselló, J.; Semperea, F.; Sanz-Berzosa, I.; Chiralt, A.; Santamarina, P. Antifungal activity and potential use of essential oils against Fusarium culmorum and Fusarium verticillioides. Journal of Essential Oil Bearing Plants, 2015, 18(2), 359-367

[62] Higueras, L.; López-Carballo, G.; Hernández-Muñoz, P.; Catalá, R.; Gavara, R. Antimicrobial packaging of chicken fillets based on the release of carvacrol from chitosan/cyclodextrin films. International journal of food microbiology, 2014, 188, 5359.

[63] Hyldgaard, M.; Mygind, T.; Meyer, R. L. Essential oils in food preservation: mode of action, synergies, and interactions with food matrix components. In: Anticrobial compounds from natural sources, ed: Mirian A. F. Hayashi, Fernando César Bizerra, Pedro Ismael Da Silva Junior. Frontiers Research topics, 2014, 36-59

[64] Sánchez-González, L.; Chiralt, A.; González-Martínez, C.; Cháfer, M. Effect of essential oils on properties of film forming emulsions and films based on hydroxypropylmethylcellulose and chitosan. Journal of Food Engineering, 2011a, 105(2), 246-253.

[65] Bonilla, J.; Atarés, L.; Vargas, M.; Chiralt, A. Effect of essential oils and homogenization conditions on properties of chitosan-based films. Food Hydrocolloids, 2012a, 26, 9-16.

[66] Jiménez, A.; Sánchez-González, L.; Desobry, S.; Chiralt, A.; Tehrany, E.A. Influence of nanoliposomes incorporation on properties of film forming dispersions and films based on corn starch and sodium caseinate, Food Hydrocolloids, 2014, 35, 159169.

[67] Requena, R.; Jiménez, A.; Vargas, M.; Chiralt, A. PHBV active bilayer films obtained by compression-molding applying essential oils at the interface. Polymer International, 2016, 65, 883-891.

[68] Zhang, H.Y.; Tehrany, E.A.; Kahn, C.J.F.; Ponçot, M.; Linder, M.; Cleymand, F. Effects of nanoliposomes based on soya, rapeseed and fish lecithins on chitosan thin films designed for tissue engineering, Carbohydrate polymers, 2012, 88, 618-627

[69] Higueras, L.; López-Carballo, G.; Cerisuelo, J. P.; Gavara, R.; Hernández-Muñoz, P. Preparation and characterization of chitosan/HP- $\beta$-cyclodextrins composites with high sorption capacity for carvacrol. Carbohydrate polymers, 2013, 97(2), 262268. 
[70] Ahmed, J.; Mulla, M. Z.; Arfat, Y. A. Thermo-mechanical, structural characterization and antibacterial performance of solvent casted polylactide/cinnamon oil composite films. Food Control, 2016, 69, 196-204.

[71] Javidi, Z.; Hosseini, S. F.; Rezaei, M. Development of flexible bactericidal films based on poly (lactic acid) and essential oil and its effectiveness to reduce microbial growth of refrigerated rainbow trout. LWT-Food Science and Technology, 2016, 72, 251-260.

[72] Salmieri, S.; Islam, F.; Khan, R. A.; Hossain, F. M.; Ibrahim, H. M.; Miao, C.; ... ; Lacroix, M. Antimicrobial nanocomposite films made of poly (lactic acid)-cellulose nanocrystals (PLA-CNC) in food applications_-part B: effect of oregano essential oil release on the inactivation of Listeria monocytogenes in mixed vegetables. Cellulose, 2014, 21(6), 4271-4285.

[73] Martínez-Abad, A.; Sánchez, G.; Fuster, V.; Lagaron, J. M.; Ocio, M. J. Antibacterial performance of solvent cast polycaprolactone (PCL) films containing essential oils. Food Control, 2013, 34(1), 214-220.

[74] Narayanan, A.; Ramana, K. V. Synergized antimicrobial activity of eugenol incorporated polyhydroxybutyrate films against food spoilage microorganisms in conjunction with pediocin. Applied Biochemistry and Biotechnology, 2013, 170(6), 1379-1388.

[75] Del Nobile, M. A.; Conte, A.; Incoronato, A. L.; Panza, O. Antimicrobial efficacy and release kinetics of thymol from zein films. Journal of Food Engineering, 2008, 89(1), 57-63.

[76] Arancibia, M.; Giménez, B.; López-Caballero, M. E.; GómezGuillén, M. C.; Montero, P. Release of cinnamon essential oil from polysaccharide bilayer films and its use for microbial growth inhibition in chilled shrimps. LWT-Food Science and Technology, 2014, 59(2), 989-995.

[77] Barba, C., Eguinoa, A.; Maté, J. I. Preparation and characterization of $\beta$-cyclodextrin inclusion complexes as a tool of a controlled antimicrobial release in whey protein edible films. LWT-Food Science and Technology, 2015, 64(2), 1362-1369.

[78] Matiacevich, S. B. Edible antimicrobial films based on microencapsulated lemongrass oil. Journal of Food Science and Technology, 2016, 53(1), 832-839.

[79] Fernández-Pan, I.; Maté, J. I.; Gardrat, C.; Coma, V. Effect of chitosan molecular weight on the antimicrobial activity and release rate of carvacrol-enriched films. Food Hydrocolloids, 2015, 51, 6068

[80] Ansorena, M.R.; Zubeldía, F.; Marcovich, N.E. Active wheat gluten films obtained by thermoplastic processing. Food Science \& Technology, 2016, 69, 47-54

[81] Petchwattana, N.; Naknaen, P. Utilization of thymol as an antimicrobial agent for biodegradable poly (butylene succinate). Materials Chemistry and Physics, 2015, 163, 369-375.

[82] Tawakkal, I. S.; Cran, M. J.; Bigger, S. W. Release of thymol from poly (lactic acid)-based antimicrobial films containing kenaf fibres as natural filler. LWT-Food Science and Technology, 2016, 66, 629-637

[83] Del Nobile, M.A.; Conte, A.; Buonocore, G.G.; Incoronato; A.L.; Massaro, A.; Panza, O. Active packaging extrusion processing of recyclable and biodegradable polymers. Journal of Food Engineering, 2009, 93, 1-6.

[84] Rusa, C.C.; Luca, C.; Tonelli, A.E. Polymer-cyclodextrin inclusion compounds: Towards new aspects of their inclusion mechanism. Macromolecules, 2001, 34, 1318-1322.

[85] Joo, M. J.; Merkel, C.; Auras, R.; Almenar, E. Development and characterization of antimicrobial poly (l-lactic acid) containing trans-2-hexenal trapped in cyclodextrins. International Journal of Food Microbiology, 2012, 153(3), 297-305.

[86] Wen, P.; Zhu, D. H.; Feng, K.; Liu, F. J.; Lou, W. Y.; Li, N.; ... ; $\mathrm{Wu}, \mathrm{H}$. Fabrication of electrospun polylactic acid nanofilm incorporating cinnamon essential oil/ $\beta$-cyclodextrin inclusion complex for antimicrobial packaging. Food chemistry, 2016, 196, 996-1004.

[87] Klangmuang, P.; Sothornvit, R. Barrier properties, mechanical properties and antimicrobial activity of hydroxypropyl methylcellulose-based nanocomposite films incorporated with Thai essential oils. Food Hydrocolloids, 2016, 61, 609-616.

[88] Otoni, C. G.; Avena-Bustillos, R. J.; Olsen, C. W.; Bilbao-Sainz, C.; McHugh, T. H. Mechanical and water barrier properties of isolated soy protein composite edible films as affected by carvacrol and cinnamaldehyde micro and nanoemulsions. Food Hydrocolloids, 2016, 57, 72-79.
[89] Shen, Z.; Kamdem, D. P. Antimicrobial activity of sugar beet lignocellulose films containing tung oil and cedarwood essential oil. Cellulose, 2015, 22(4), 2703-2715.

[90] Hosseini, S. F.; Rezaei, M.; Zandi, M.; Farahmandghavi, F. Biobased composite edible films containing Origanum vulgare L. essential oil. Industrial Crops and Products, 2015, 67, 403-413.

[91] Martucci, J. F.; Gende, L. B.; Neira, L. M.; Ruseckaite, R. A Oregano and lavender essential oils as antioxidant and antimicrobial additives of biogenic gelatin films. Industrial Crops and Products, 2015, 71, 205-213.

[92] Galus, S.; Kadzińska, J. Whey protein edible films modified with almond and walnut oils. Food Hydrocolloids, 2016, 52, 78-86.

[93] Sánchez-González, L.; Vargas, M.; González-Martínez, C.; Chiralt, A.; Cháfer, M. Characterization of edible films based on hydroxypropylmethylcellulose and tea tree essential oil. Food Hydrocolloids, 2009, 23(8), 2102-2109.

[94] Perez-Gago, M. B.; Krochta, J. M. Lipid particle size effect on water vapor permeability and mechanical properties of whey protein-beeswax emulsion films. Journal of Agricultural and Food Chemistry, 2001, 49(2), 996-1002.

[95] Atarés, L.; Bonilla, J.; Chiralt, A. Characterization of sodium caseinate-based edible films incorporated with cinnamon or ginger essential oils. Journal of Food Engineering, 2010a, 100(4), 678687.

[96] Bonilla, J.; Atarés, L.; Vargas, M.; Chiralt, A. Edible films and coatings to prevent the detrimental effect of oxygen on food quality: possibilities and limitations. Journal of Food Engineering, 2012b, 110(2), 208-213.

[97] Bonilla, J.; Talón, E.; Atarés, L.; Vargas, M.; Chiralt, A. Effect of the incorporation of antioxidants on physicochemical and antioxidant properties of wheat starch-chitosan films. Journal of Food Engineering, 2013, 118(3), 271-278.

[98] Atarés, L.; De Jesús, C.; Talens, P.; Chiralt, A. Characterization of SPI-based edible films incorporated with cinnamon or ginger essential oils. Journal of Food Engineering, 2010b, 99(3), 384-391.

[99] Tongnuanchan, P.; Benjakul, S.; Prodpran, T. Properties and antioxidant activity of fish skin gelatin film incorporated with citrus essential oils. Food Chemistry, 2012, 134(3), 1571-1579.

[100] Fernández-Pan, I.; Maté, J. I.; Gardrat, C.; Coma, V. Effect of chitosan molecular weight on the antimicrobial activity and release rate of carvacrol-enriched films. Food Hydrocolloids, 2015, 51, 6068

[101] Commission of the European Communities, Comission Directive 97/48/EC of 29 July amending Council Directive 82/711/EEC laying down the basic rules necessary for testing migration of the constituents of plastics materials and articles intended to come into contact with foodstuffs, Official Journal of the European Communities, 12 August 1997, no. L 222, p 10.

[102] Etxabide, A.; Uranga, J.; Guerrero, P.; de la Caba, K. Development of active gelatin films by means of valorisation of food processing waste: A review. Food Hydrocolloids, 2016, 1-7.

[103] Crank, J. T. The mathematics of diffusion. Oxford, 1975

[104] Ritger, P.L.; Peppas, N.A. A simple equation for description of solute release I. Fickian and non-fickian release from non-swellable devices in the form of slabs, spheres, cylinders or discs. Journal of controlled release, 1987a, 5(1), 23-36.

[105] Ritger, P.L.; Peppas, N.A. A simple equation for description of solute release II. Fickian and anomalous release from swellable devices. Journal of controlled release, 1987b, 5(1), 37-42.

[106] Biddeci, G.; Cavallaro, G.; Di Blasi, F.; Lazzara, G.; Massaro, M.; Milioto, S.; ...; Spinelli, G. Halloysite nanotubes loaded with peppermint essential oil as filler for functional biopolymer film. Carbohydrate Polymers, 2016, 152, 548-557.

[107] Sánchez-González, L.; Cháfer, M.; González-Martínez, C.; Chiralt, A.; Desobry, S. Study of the release of limonene present in chitosan films enriched with bergamot oil in food simulants. Journal of Food Engineering, 2011d, 105(1), 138-143.

[108] Tehrany, E. A.; Desobry, S. Partition coefficient of migrants in food simulants/polymers systems. Food Chemistry, 2007, 101(4), 1714-1718

[109] Moradi, M.; Tajik, H.; Razavi Rohani, S. M.; Oromiehie, A. R. Effectiveness of Zataria multiflora Boiss essential oil and grape seed extract impregnated chitosan film on ready-to-eat mortadella-type sausages during refrigerated storage. Journal of the Science of Food and Agriculture, 2011, 91(15), 2850-2857.

[110] Wu, J.; Liu, H.; Ge, S.; Wang, S.; Qin, Z.; Chen, L.; ... ; Zhang, Q. The preparation, characterization, antimicrobial stability and in 
vitro release evaluation of fish gelatin films incorporated with cinnamon essential oil nanoliposomes. Food Hydrocolloids, 2015, 43, 427-435.

[111] Castro, D. O.; Tabary, N.; Martel, B.; Gandini, A.; Belgacem, N.; Bras, J. Effect of different carboxylic acids in cyclodextrin functionalization of cellulose nanocrystals for prolonged release of carvacrol. Materials Science and Engineering: C, 2016, 69, 1018102

[112] Chen, H.; Hu, X.; Chen, E.; Wu, S.; McClements, D. J.; Liu, S.; ... ; $\mathrm{Li}$, Y. Preparation, characterization, and properties of chitosan films with cinnamaldehyde nanoemulsions. Food Hydrocolloids, 2016, 61, 662-671.

[113] Giménez, B.; Gómez-Guillén, M. C.; López-Caballero, M. E.; Gómez-Estaca, J.; Montero, P. Role of sepiolite in the release of active compounds from gelatin-egg white films. Food Hydrocolloids, 2012, 27(2), 475-486.

[114] Bonilla, J.; Vargas, M.; Atarés, L.; Chiralt, A. Effect of chitosan essential oil films on the storage-keeping quality of pork meat products. Food Bioprocess Technology, 2014, 7(8), 2443-2450

[115] Özvural, E. B.; Huang, Q.; Chikindas, M. L. The comparison of quality and microbiological characteristic of hamburger patties enriched with green tea extract using three techniques: Direct addition, edible coating and encapsulation. LWT-Food Sci. Technol., 2016, 68, 385-390.

[116] Kakaei, S.; Shahbazi, Y. Effect of chitosan-gelatin film incorporated with ethanolic red grape seed extract and Ziziphora clinopodioides essential oil on survival of Listeria monocytogenes and chemical, microbial and sensory properties of minced trout fillet. LWT-Food Science and Technology, 2016, 72, 432-438.

117] Raybaudi-Massilia, R. M.; Mosqueda-Melgar, J.; Martín-Belloso, $\mathrm{O}$. Edible alginate-based coating as carrier of antimicrobials to improve shelf-life and safety of fresh-cut melon. International Journal of Food Microbiology, 2008, 121(3), 313-327.

[118] Salvia-Trujillo, L.; Rojas-Graü, M. A.; Soliva-Fortuny, R.; MartínBelloso, O. Use of antimicrobial nanoemulsions as edible coatings: Impact on safety and quality attributes of fresh-cut Fuji apples. Postharvest Biology and Technology, 2015, 105, 8-16.

[119] Gómez-Estaca, J.; Montero, P.; Giménez, B.; Gómez-Guillén, M. C. Effect of functional edible films and high pressure processing on microbial and oxidative spoilage in cold-smoked sardine (Sardina pilchardus). Food Chemistry, 2007, 105(2), 511-520.

[120] Kazemi, S. M.; Rezaei, M. Antimicrobial effectiveness of gelatinalginate film containing oregano essential oil for fish preservation. Journal of Food Safety, 2015, 35(4), 482-490

[121] Ayala-Zavala, J. F.; Silva-Espinoza, B. A.; Cruz-Valenzuela, M. R.; Leyva, J. M.; Ortega-Ramírez, L. A.; Carrazco-Lugo, D. K.;...; Miranda, M. R. A. Pectin-cinnamon leaf oil coatings add antioxidant and antibacterial properties to fresh-cut peach. Flavour and Fragrance Journal, 2013, 28(1), 39-45.

[122] Ravishankar, S.; Zhu, L.; Olsen, C. W.; McHugh, T. H.; Friedman, M. Edible apple film wraps containing plant antimicrobials inactivate foodborne pathogens on meat and poultry products. Journal of Food Science, 2009, 74(8), M440-M445.

[123] Balaguer, M. P.; Lopez-Carballo, G.; Catala, R., Gavara, R.; Hernandez-Munoz, P. Antifungal properties of gliadin films incorporating cinnamaldehyde and application in active food packaging of bread and cheese spread foodstuffs. International Journal of Food Microbiology, 2013, 166(3), 369-377.

[124] Oussalah, M.; Caillet, S.; Salmiéri, S.; Saucier, L.; Lacroix, M. Antimicrobial and antioxidant effects of milk protein-based film containing essential oils for the preservation of whole beef muscle. Journal of Agricultural and Food Chemistry, 2004, 52(18), 5598-5605.

[125] Zinoviadou, K. G.; Koutsoumanis, K. P.; Biliaderis, C. G. Physicochemical properties of whey protein isolate films containing oregano oil and their antimicrobial action against spoilage flora of fresh beef. Meat Science, 2009, 82(3), 338-345.

[126] Fernández-Pan, I.; Carrión-Granda, X.; Maté, J. I. Antimicrobial efficiency of edible coatings on the preservation of chicken breast fillets. Food Control, 2014, 36 (1), 69-75.

[127] Petersen, K.; Nielsen, P. V.; Bertelsen, G.; Lawther, M.; Olsen, M. B.; Nilsson, N. H.; Mortensen, G. Potential of biobased materials for food packaging. Trends in Food Science \& Technology, 1999, 10(2), 52-68.

[128] Takala, P. N.; Salmieri, S.; Boumail, A.; Khan, R. A.; Vu, K. D.; Chauve, G.; ... ; Lacroix, M. Antimicrobial effect and physicochemical properties of bioactive trilayer polycaprolactone/methylcellulose-based films on the growth of foodborne pathogens and total microbiota in fresh broccoli. Journal of Food Engineering, 2013, 116(3), 648-655.

[129] Corre, Y.M.; Bruzaud, S.; Audic, J.L.; Grohens, Y. Morphology and functional properties of commercial polyhydroxyalkanoates: a comprehensive and comparative study. Polymer Testing, 2012, 31, 226-235.

[130] Tassou, C. C.; Drosinos, E. H.; Nychas, G. J. E. Effects of essential oil from mint (Mentha piperita) on Salmonella enteritidis and Listeria monocytogenes in model food systems at 4 and 10 ${ }^{\circ} \mathrm{C}$. Journal of Applied Bacteriology, 1995, 78 (6), 593-600.

[131] Shelef, L. A.; Jyothi, E. K.; Bulgarellii, M. A. Growth of enteropathogenic and spoilage bacteria in sage-containing broth and foods. Journal of Food Science, 1984, 49 (3), 737-740.

[132] Aureli, P.; Costantinf, A.; Zolea, S. Antimicrobial activity of some plant essential oils against Listeria monocytogenes. Journal of Food Protection, 1992, 55 (5), 344-348.

[133] Pandit, V. A.; Shelef, L. A. Sensitivity of Listeria monocytogenes to rosemary (Rosmarinus officinalis L.). Food Microbiology, 1994, 11 (1), 57-63.

[134] Gill, A. O.; Delaquis, P.; Russo, P.; Holley, R. A. Evaluation of antilisterial action of cilantro oil on vacuum packed ham. International journal of food microbiology, 2002, 73(1), 8392.

[135] Shekarforoush, S. S.; Nazer, A. H. K.; Firouzi, R.; Rostami, M. Effects of storage temperatures and essential oils of oregano and nutmeg on the growth and survival of Escherichia coli O157: H7 in barbecued chicken used in Iran. Food Control, 2007, 18(11), 14281433.

[136] Uhart, M.; Maks, N.; Ravishankar, S. Effect of spices on growth and survival of Salmonella typhimurium DT 104 in ground beef stored at 4 and $8{ }^{\circ} \mathrm{C}$. Journal of Food Safety, 2006, 26(2), 115-125.

[137] Firouzi, R.; Shekarforoush, S. S.; Nazer, A. H. K.; Borumand, Z.; Jooyandeh, A. R. Effects of essential oils of oregano and nutmeg on growth and survival of Yersinia enterocolitica and Listeria monocytogenes in barbecued chicken. Journal of Food Protection, 2007, 70(11), 2626-2630.

[138] Veldhuizen, E. J.; Creutzberg, T. O.; Burt, S. A.; Haagsman, H. P. Low temperature and binding to food components inhibit the antibacterial activity of carvacrol against Listeria monocytogenes in steak tartare. Journal of Food Protection, 2007, 70(9), 2127-2132.

[8] Mackel, H. Capturing the Spectra of Silicon Solar Cells. PhD Thesis, The Australian National University: Canberra, December 2004. 